\title{
Coordinated gene expression during gilthead sea bream skeletogenesis and its disruption by nutritional hypervitaminosis $\mathrm{A}$
}

\author{
Ignacio Fernández ${ }^{1 *}$, Maria Darias ${ }^{1}$, Karl B Andree ${ }^{1}$, David Mazurais² ${ }^{2}$ Jose Luís Zambonino-Infante ${ }^{2}$, Enric Gisbert ${ }^{1}$
}

\begin{abstract}
Background: Vitamin A (VA) has a key role in vertebrate morphogenesis, determining body patterning and growth through the control of cell proliferation and differentiation processes. VA regulates primary molecular pathways of those processes by the binding of its active metabolite (retinoic acid) to two types of specific nuclear receptors: retinoic acid receptors (RARs) and retinoid $X$ receptors (RXRs), which promote transcription of downstream target genes. This process is well known in most of higher vertebrates; however, scarce information is available regarding fishes. Therefore, in order to gain further knowledge of fish larval development and its disruption by nutritional VA imbalance, the relative expression of some RARs and RXRs, as well as several genes involved in morpho- and skeletogenesis such as peroxisome proliferator-activated receptors (PPARA, PPARB and PPARG); retinol-binding protein (RBP); insulin-like growth factors I and II (IGF1 and IGF2, respectively); bone morphogenetic protein 2 (Bmp2); transforming growth factor $\beta-1$ (TGFB1); and genes encoding different extracellular matrix (ECM) proteins such as matrix Gla protein (mgp), osteocalcin (bglap), osteopontin (SPP1), secreted protein acidic and rich in cysteine (SPARC) and type I collagen $\alpha 1$ chain (COL1A1) have been studied in gilthead sea bream.

Results: During gilthead sea bream larval development, specific expression profiles for each gene were tightly regulated during fish morphogenesis and correlated with specific morphogenetic events and tissue development. Dietary hypervitaminosis A during early larval development disrupted the normal gene expression profile for genes involved in RA signalling (RARA), VA homeostasis (RBP) and several genes encoding ECM proteins that are linked to skeletogenesis, such as bglap and mgp.

Conclusions: Present data reflects the specific gene expression patterns of several genes involved in larval fish RA signalling and skeletogenesis; and how specific gene disruption induced by a nutritional VA imbalance underlie the skeletal deformities. Our results are of basic interest for fish VA signalling and point out some of the potential molecular players involved in fish skeletogenesis. Increased incidences of skeletal deformities in gilthead sea bream fed with hypervitaminosis A were the likely ultimate consequence of specific gene expression disruption at critical development stages.
\end{abstract}

\section{Background}

Skeletogenesis is a critical process in vertebrates during which the skeleton develops in a genetically programmed manner, leading to normal anatomy that provides support and protection for the internal organs. In mammals, this process includes the differentiation and proliferation of different cell types, such as chondrocytes, osteoblasts,

\footnotetext{
* Correspondence: ignacio.fernandez@irta.es

'Unitat de Cultius Experimentals, IRTA Centre de Sant Carles de la Ràpita (IRTA-SCR), Crta. del Poble Nou s/n, 43540 - Sant Carles de la Ràpita (Spain) Full list of author information is available at the end of the article
}

osteocytes and osteoclasts, which determine the size, shape and mineral composition of bone structures. The expression of specific genes deeply underlies these processes of cell proliferation and differentiation, which are also controlled by biotic and abiotic factors as well as individual genetic characteristics. Thus, determining factors and conditions that control and perturb those processes at the transcriptional level could be useful for deciphering the specific mechanisms behind these processes.

Teleost fish are considered to be the first vertebrate group to develop a bony skeleton, and with it, the

\section{Biomed Central}


molecular machinery necessary for its formation and maintenance. Thus, fish have been recognized as a suitable vertebrate model for understanding skeletogenesis in lower and higher vertebrates for both comparative [1] and evolutionary [2] purposes. In addition, marine fish larvae hatch much earlier in their development than other vertebrates, suggesting that the spatiotemporal sequences of the skeletal development in teleosts are quite different from those of higher vertebrates [3]. This makes marine fish species a very interesting model to study the influence of several nutrients, such as vitamin $\mathrm{A}$, in morphogenesis and skeletogenesis during early larval development [4].

Nutritional research has recently focused on the role of nutrients on gene expression and regulation (nutrigenomics) [5]. The main pathway by which some nutrients control gene expression is by the activation of transcription factors, with the nuclear receptor superfamily being one of the most important. Within this family, the retinoic acid receptors (RARs) and retinoid $\mathrm{X}$ receptors (RXRs) are the specific receptors that transduce the vitamin A (VA) signalling by binding to their specific ligands, the retinoic acid isomers. RARs and RXRs have been found in all vertebrate tissues examined, and within both are present three different isotypes $(\alpha, \beta$ and $\gamma$ ), each one encoded by a separate gene. These RARs and RXRs bind to retinoic acid (RA, the main active metabolite of VA), becoming ligand-activated receptors. Then, they form homo- and/or heterodimers that bind to specific nucleotide sequences (retinoic acid response elements, RAREs) in the promoter region of a large number of genes [6,7], regulating their transcriptional activity. These RARs and RXRs can also affect indirectly the transcription of many other genes without any RARE in their promoter [6]. Then, through those molecular pathways, RA plays a key role in morphogenesis, cellular proliferation and differentiation processes of bone formation [8].

Skeletogenesis has been extensively described in several marine fish species [9-12], but gene expression patterns during larval development have only been partially characterized in European sea bass (Dicentrarchus labrax; $[13,14])$ and gilthead sea bream (Sparus aurata; [15]). In addition, studies have shown that fish fed diets with deficient or excess VA content had compromised development, showing reduced growth and survival rate, delayed digestive system maturation and high incidence of skeletal deformities [16-22]. However, while most reports are related to the consequences of dietary VA imbalance, limited work has focused on the molecular pathways involved in retinoid homeostasis that leads to an abnormal fish phenotype [23]. Moreover, such works have focused mainly on embryonic development rather than larval development [24-26]. Therefore, following our previous work on the description of abnormal phenotypes in gilthead sea bream larvae fed with hypervitaminosis A [18], in the present study we evaluated the relative expression of several genes involved in gilthead sea bream morpho- and skeletogenesis during larval development, and their disruption when fish were fed with high VA doses. In addition to retinoic acid receptors (RARA, RARG and RXRB), we evaluated the expression of different genes interacting with the RA signalling pathway, such as peroxisome proliferator-activated receptors (PPARA, PPARB and PPARG) that act as regulators of lipid and lipoprotein metabolism, glucose homeostasis, cellular proliferation and differentiation, as well as apoptosis in mammals [27]; the gene encoding retinol-binding protein $(R B P)$ as the main protein that specifically transports retinol from liver to peripheral tissues [28]; and insulin-like growth factors I and II (IGF1 and $I G F 2$, respectively), which control cell growth and proliferation. Bone morphogenetic protein $2(B m p 2)$ and transforming growth factor $\beta-1$ (TGFB1) were also studied as they are key transcriptional factors for normal development [29], controlling the production of different extracellular matrix (ECM) proteins of bone. Additionally, relative expression of genes encoding different ECM proteins was evaluated such as matrix Gla protein ( $m g p)$ and osteocalcin (bglap, also known as bone Gla protein) as important regulators of calcium metabolism and skeletal development; osteopontin (SPP1) and secreted protein acidic and rich in cysteine (SPARC), as examples of important matricellular proteins acting as modulators of ECM interactions; and type I collagen $\alpha 1$ chain (COL1A1), which represents $90 \%$ of collagen proteins in bone tissues. Present results, describing the expression of several genes involved in gilthead sea bream morpho- and skeletogenesis processes under standard larval rearing conditions and their disruption of expression under hypervitaminosis A regimens, are of basic interest for understanding normal skeletogenesis and the appearance of skeletal deformities, as well as a tool for assessing fish nutritional VA imbalance.

\section{Results}

\section{Gilthead sea bream larval growth and bone mineralization}

Larval growth in standard length (SL) and dry weight (DW) under standard rearing conditions are presented in Figure 1. Growth in DW and SL shows the typical exponential and linear increase with age, respectively. Growth performance of larval rearing under hypervitaminosis A conditions was affected by the level of dietary VA [18]. Whereas no clear effects were found in larval SL at 18 days post hatch $(\mathrm{dph})$, larvae fed with the highest dietary VA content $(10 \times \mathrm{VA} ; 10$ - fold VA increase in relation to the control diet) were significantly smaller $(7 \%)$ than the 


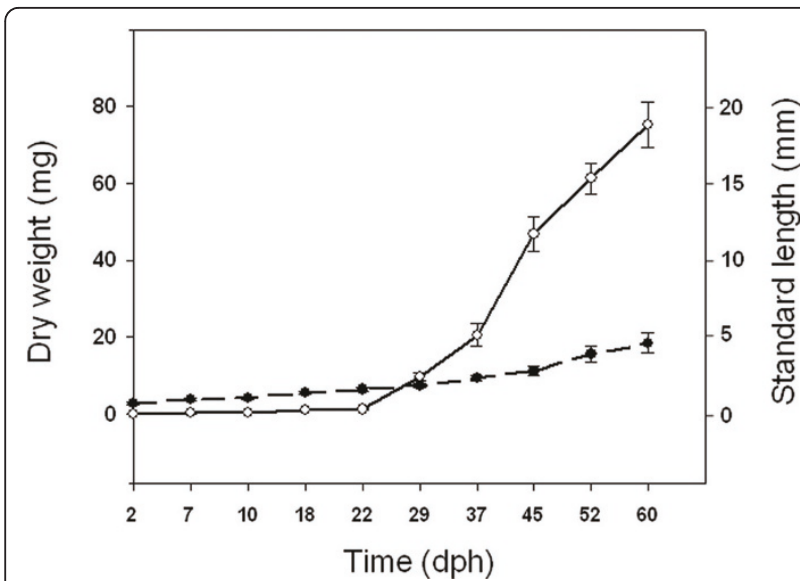

Figure 1 Gilthead sea bream larval growth from 2 to $60 \mathrm{dph}$ Growth in standard length (long dash line) was measured in $\mathrm{mm}$ and weight in $\mathrm{mg}$ dry weight (solid line). Values are expressed as mean \pm standard deviation. Equation of the linear regression for the growth in standard length was $y=1,6562 x-0,666\left(R^{2}=0,9112\right)$, while the exponential regression line for the growth in dry weight was $y=0,0252 e^{0,8815 x}\left(R^{2}=0,9614\right)$.

control group at $60 \mathrm{dph}$. Similarly, no differences in DW were found between experimental groups at $18 \mathrm{dph}$, while at $60 \mathrm{dph} 10 \times \mathrm{VA}$ larvae $(56.86 \pm 11.27 \mathrm{mg})$ presented a reduction of $27 \%$ in DW with respect to control and 1.5 $\times$ VA (1.5-fold VA increase in relation to the control diet) larvae $(74.61 \pm 8.84$ and $69.31 \pm 10.24 \mathrm{mg}$, respectively).

Regarding the bone mineralization of larvae, bone and cartilage staining quantification performed by IMAQ Vision Builder is summarized in Figure 2. Mineralization values were expressed as the ratio of red/blue colour as well as the specific amounts of each colour per larval surface, from stained fish for each experimental group. There were three patterns observed (Figure 3): (i) in control larvae most of the structures were red coloured with the exception of few structures (mainly pterygiophores and sclerotic related structures); (ii) the $1.5 \times$ VA larvae had many structures quite blue in colouration (pectoral and caudal fin related structures, pterygiophores, and splanchnocranium related structures such as frontral, pterotic, sphenotic and sclerotic related structures); and (iii) in the $10 \times$ VA larvae blue colouration was intermediate with respect to the previously enumerated structures of $1.5 \times \mathrm{VA}$ larvae (skeletal structure nomenclature was as in [9-11]). Mineralization values in $1.5 \times \mathrm{VA}$ and $10 \times \mathrm{VA}$ larvae at 60 $\mathrm{dph}$ were higher than in the control group, although there were no significant differences (ANOVA, $P>0.05$; Figure 2a). The absence of a statistically significant difference between treatments is likely due to the high variability observed among replicates from each treatment. Interestingly, significantly higher cartilage staining was found in

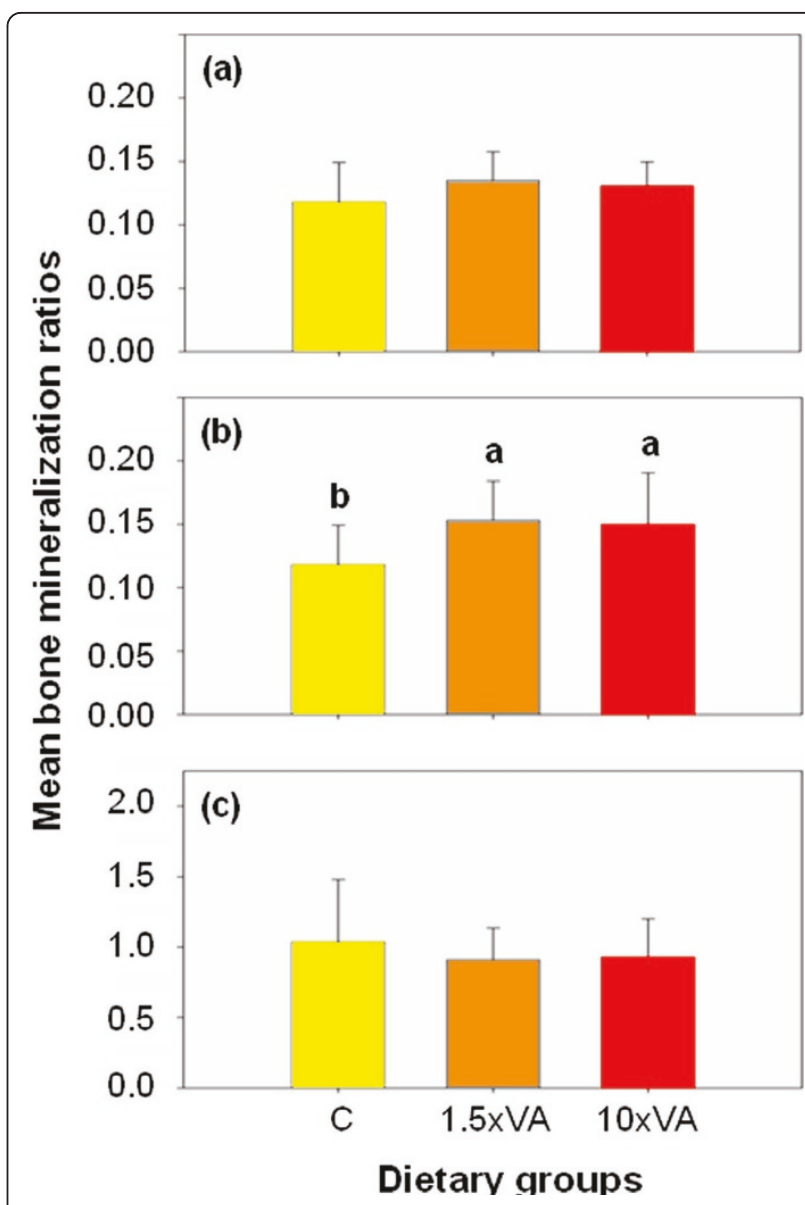

Figure 2 Gilthead sea bream bone mineralization at $60 \mathrm{dph}$ of fishes from the different dietary treatments. Bone mineralization measured as ratios of red pixels (a), blue pixels per larval surface (b), and red pixels over blue pixels (c). Ratios are expressed as mean \pm standard deviation. Letters denotes significant differences between dietary groups (ANOVA, $P<0.05 ; n=26$ larvae per treatment). C, larvae fed with control diet $\left(0.66^{*} 10^{8}\right.$ total VA IU kg $\left.{ }^{-1} \mathrm{DW}\right) ; 1.5 \times \mathrm{VA}$, larvae fed with 1.5 fold increase in dietary VA content $\left(1.00^{*} 10^{8}\right.$ total VA IU kg $\left.{ }^{-1} \mathrm{DW}\right) ; 10 \times V A$, larvae fed with 10 fold increase in dietary VA content $\left(6.82^{*} 10^{8}\right.$ total VA IU kg $\left.{ }^{-1} \mathrm{DW}\right)$.

$1.5 \times \mathrm{VA}$ and $10 \times \mathrm{VA}$ larvae with respect to the control group (ANOVA; $P<0.05$; Figure $2 \mathrm{~b}$ ). In addition, the ratio of red/blue coloration (bone/cartilage mineralization) showed that both larvae fed with VA supplemented diets $(1.5 \times \mathrm{VA}$ and $10 \times \mathrm{VA})$ had lower values than the control group; although this tendency was not statistically significant (ANOVA, $P>0.05$; Figure 2c).

\section{Gene expression patterns during gilthead sea bream ontogeny development under standard rearing conditions}

During larval development, RA nuclear receptors, $R A R A$, $R A R G$ and $R X R B$, exhibited different expression patterns in gilthead sea bream (Figure 4). Under our rearing 


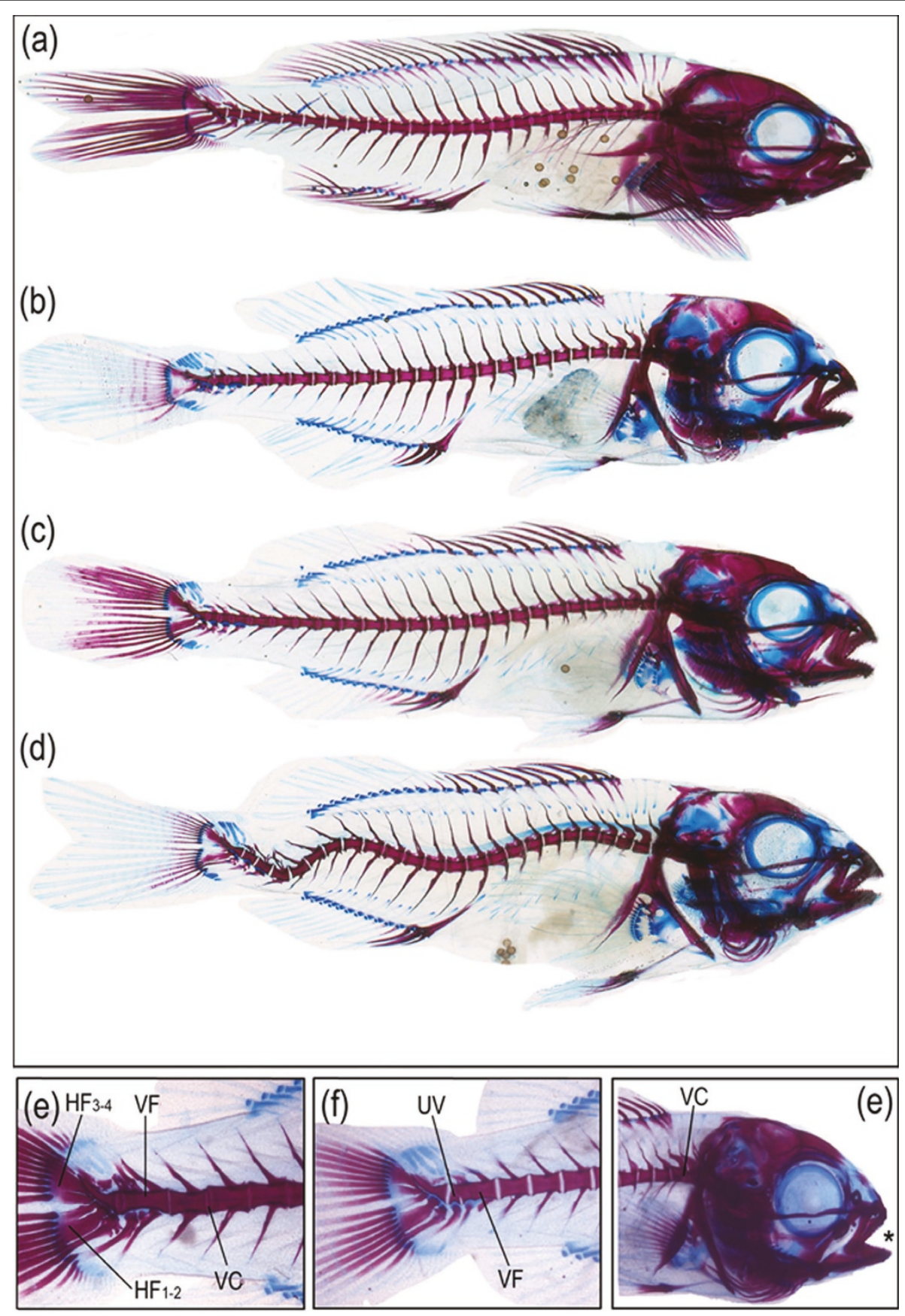

Figure 3 Examples of double stained fish with alcian blue/alizarin red from different dietary treatments showing different levels of ossifications and typologies of skeletal deformities. (a) Larva fed with control diet $\left(0.66^{*} 10^{8}\right.$ total VA IU kg $\left.{ }^{-1} \mathrm{DW}\right)$ exhibiting mostly red coloured skeletal structures (calcified bone) with the exception of pterygiophores and sclerotic elements still stained with alcian blue (cartilage). (b) Larva fed moderately increased levels of VA (1.5XVA group, $1.00^{*} 10^{8}$ total VA IU kg-1 DW) showing a larger proportion of skeletal structures stained in blue (cartilage) in comparison to the control group; e.g. pectoral fin girdle, epurals, parahypural and specialized neural arch in the caudal fin complex, and frontal, pterotic and parietal bones in the cranium. (c) Larva fed with the highest levels of VA (10XVA group, $6.82^{*} 10^{8}$ total VA IU kg-1 DW) showing intermediate values in blue colouration with regards to the control group. The skeletal structures stained in blue (cartilage) are those already reported in the larva from the 1.5XVA group. (d) Larva showing a severe deformity (double lordosis and kyphosis) affecting haemal vertebrae. (e) Deformed caudal fin complex showing the fusion of the hypurals 3-4 (HF3-4) and 1-2 (HF1-2), as well as the fusion (VF) and compression (VC) of different haemal vertebrae centra (23-24 and 22-23, respectively). (f) Fusion of vertebral bodies (VF) from haemal vertebrae number 22 and 23 and underdevelopment of vertebrae 24 (UV). (e) Head of a larva with a slight prognathism (asterisk) due to an underdevelopment of the premaxillar and maxillar bones, and vertebral compression (VC) between centra of prehaemal vertebrae number 2 and 3. 


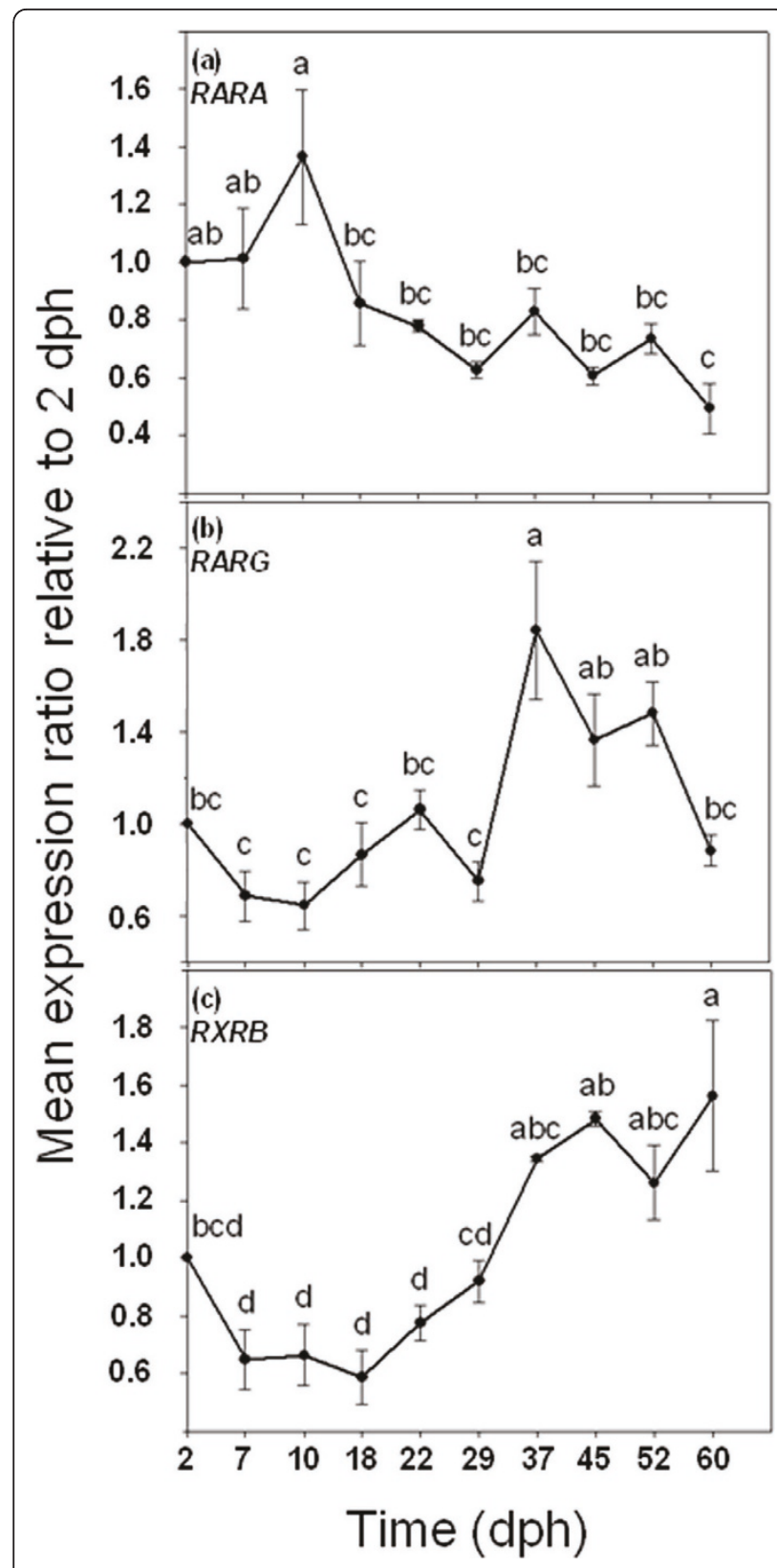

Figure 4 Ontogenetic gene expression patterns of RARA (a), RARG (b) and $R X R B$ (c). Gene expression measured as the mean expression ratio of the target gene with respect to the housekeeping gene $(E F I \alpha)$ at each sample time compared with initial

conditions, gilthead sea bream larvae showed a high overall level of RARA gene expression until $10 \mathrm{dph}$, after which levels decreased significantly and thereafter remained constant until the end of the experiment (60 dph) (ANOVA, $P<0.05$; Figure 4a). Conversely, the expression of RARG and $R X R B$ were lower during the initial larval development, after which the levels increased. However, while RARG increased significantly from $29 \mathrm{dph}$, with a peak at $37 \mathrm{dph}$ (1.8 fold change compared to $2 \mathrm{dph}$ ), its expression level significantly decreased at $60 \mathrm{dph}$ (ANOVA, $P<0.05$; Figure $4 \mathrm{~b}$ ) with respect to the levels at $37 \mathrm{dph}$. The expression of $R X R B$ increased significantly only between 29 and $60 \mathrm{dph}$ (ANOVA, $P<0.05$; Figure 4 c).

There were no significant differences in the RBP gene expression profile during the larval development (ANOVA, $P>0.05$; Figure 5a). PPARA expression was constant from 2 to $37 \mathrm{dph}$, whereas at $45 \mathrm{dph}$ a peak of gene expression was noted (2.94 fold increase with respect to $2 \mathrm{dph}$ larvae; $P<0.05$; Figure $5 \mathrm{~b}$ ). $P P A R B$ expression remained constant from 2 to $60 \mathrm{dph}$ (ANOVA, $P>0.05$; Figure $5 \mathrm{c}$ ). The PPARG expression level did not change from 2 to $52 \mathrm{dph}$; however, at the end of the study (60 dph), expression values were significantly higher than those mostly observed between 7 and $37 \mathrm{dph}$ (ANOVA, $P<0.05$; Figure $5 \mathrm{~d}$ ), but not significantly different to those observed at $2 \mathrm{dph}$.

Overall, the IGF1 and IGF2 gene expression had significantly increased at the end of larval development. However, while IGF1 gene expression increased significantly and progressively from 0.54 at $7 \mathrm{dph}$ to 6.52 at $60 \mathrm{dph}$ (ANOVA, $P<0.05$; Figure 5e), IGF2 expression remained constant from 2 to $29 \mathrm{dph}$ (ANOVA, $P>$ 0.05; Figure 5f). Expression values of IGF2 increased significantly between 37 and $45(1.43 \pm 0.06$ mean expression ratio; ANOVA, $P<0.05$; Figure $5 f$ ) and remained constant until the end of the study. Bmp2 did not show significant variations in its mean gene expression ratio throughout larval development (ANOVA, $P>0.05$ ), although a tendency for higher expression values was observed from $37 \mathrm{dph}$ onwards (Figure $5 \mathrm{~g}$ ). Interestingly, TGFB1 presented an overall significant increase in its gene expression ratio from $29 \mathrm{dph}$ until the end of the trial (ANOVA, $P<0.05$; Figure $5 \mathrm{~h}$ ).

With respect to the expression patterns of genes encoding ECM proteins during larval development, all of them increased at the end of the study. However, the mean gene expression ratios reached at the end of the experiment by each gene were different. The genes $m g p$ and bglap showed the highest mean expression ratios at 60 dph (199.38 and 7956.15, respectively; ANOVA, $P<$ 0.05 ; Figure $6 \mathrm{a}, \mathrm{b})$. In both Gla protein genes, a significant increase in the mean gene expression ratio was observed near the end of the trial (around $45 \mathrm{dph}$ ). In contrast, SPP1 and SPARC showed lower mean values (23.38 and 3.25, respectively) at the end of the experiment (Figure 6c and 6d, respectively) compared with $m g p$ and bglap ratios, although presenting significant increases as well in comparison to results from early larval stages (ANOVA, $P<0.05$ ). Furthermore, both SPP1 and SPARC showed a significant increase at $37 \mathrm{dph}$ in their mean gene expression ratios, earlier than $m g p$ and 


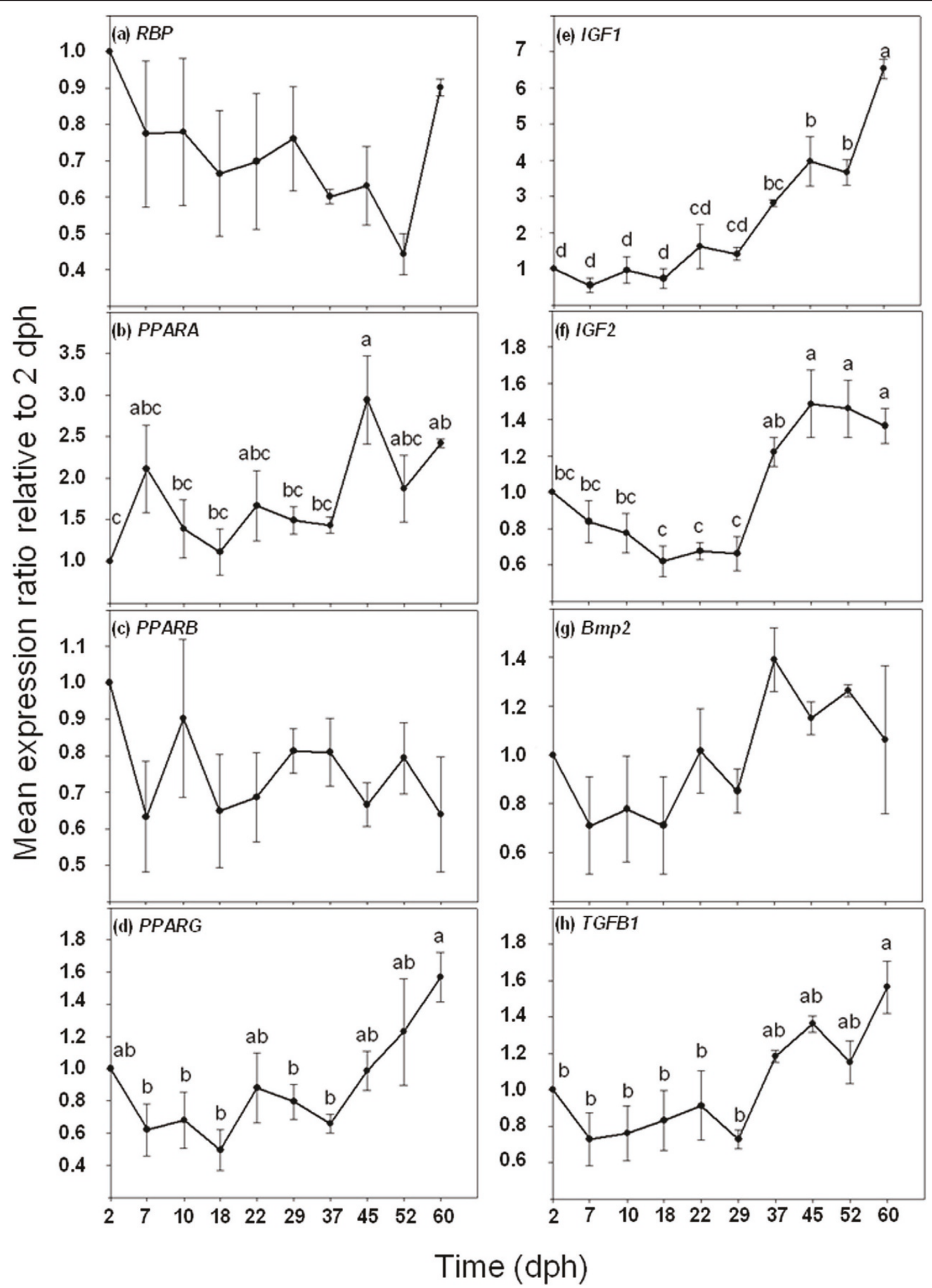

Figure 5 Ontogenetic gene expression patterns of RBP (a), PPARA (b), PPARB (c), PPARG (d), IGF1 (e), IGF2 (f), Bmp2 (g), and TGFB1 (h). Gene expression measured as the mean expression ratio of the target gene with respect to the house-keeping gene $(E F / \alpha)$ at each sample time compared with initial sample time ( $2 \mathrm{dph}$ ). Different letters denote significant differences of the global gene expression (ANOVA, $P<0.05 ; n=3$ ). 


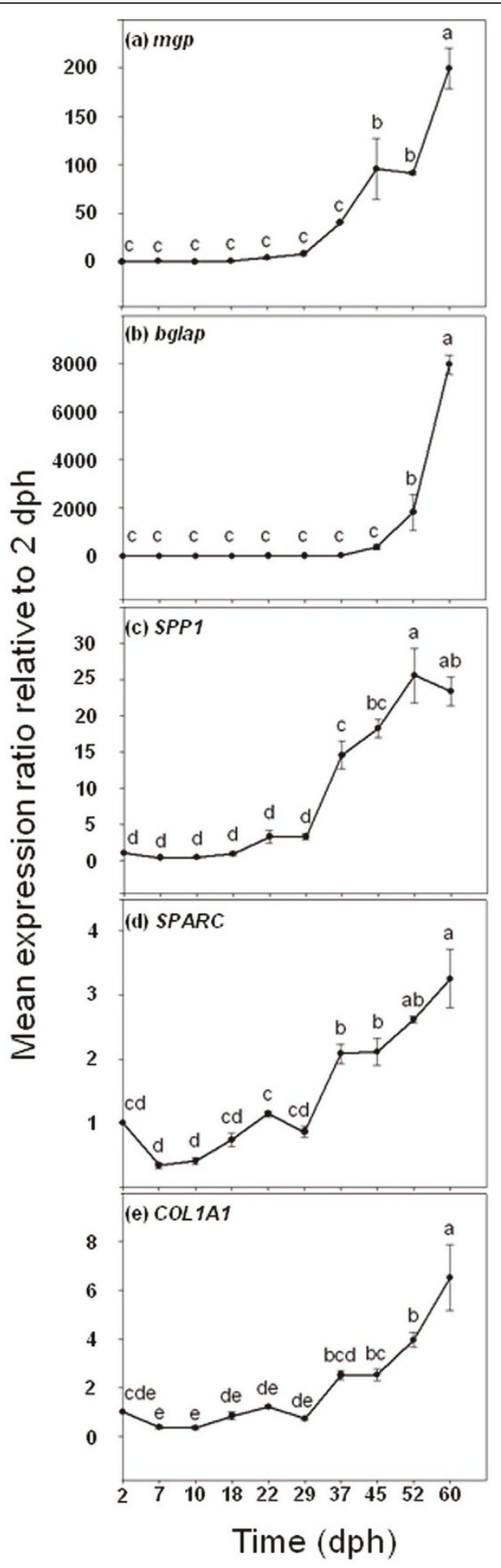

Figure 6 Ontogenetic gene expression patterns of $m g p$ (a), bglap (b), SPP1 (c), SPARC (d), and COL1A1 (e). Gene expression measured as the mean expression ratio of the target gene respect to the house-keeping gene $(E F T \alpha)$ at each sample time compared with initial sample time (2 dph). Different letters denote significant differences of the global gene expression (ANOVA, $P<0.05 ; n=3$ ). bglap. Finally, COL1A1 presented a similar gene expression profile to those of other ECM protein genes, with a significant increase in the mean gene expression ratio at $60 \mathrm{dph}$ (ANOVA, $P<0.05$; Figure 6e).

Global hierarchical clustering was applied on the gene expression ratios during larval development for the 16 studied genes (Figure 7). This clustering was used to classify genes on the basis of similarity of their expression profile during larval development sampling times. Two gene clusters were found: (i) genes whose mean gene expression level increased from $37 \mathrm{dph}$, such as IGF1, TGFB1, RXRB, IGF2 and genes encoding extracellular matrix proteins ( $m g p$, bglap, SPP1, SPARC and COL1A1); and (ii) genes whose mean gene expression ratio decreased progressively from an initial relatively high level of expression (PPARB, RARA and RBP).

\section{Gene expression in gilthead sea bream larvae fed with increasing levels of dietary VA}

At $18 \mathrm{dph}$, larvae fed with increasing dietary VA levels exhibited disruption in the expression of several studied genes. While some of them showed an up-regulation, others were down-regulated with respect to the control feeding regime. That gene disruption was also noted in some genes even when the dietary VA imbalance had finished more than 40 days before ( $60 \mathrm{dph}$ ).

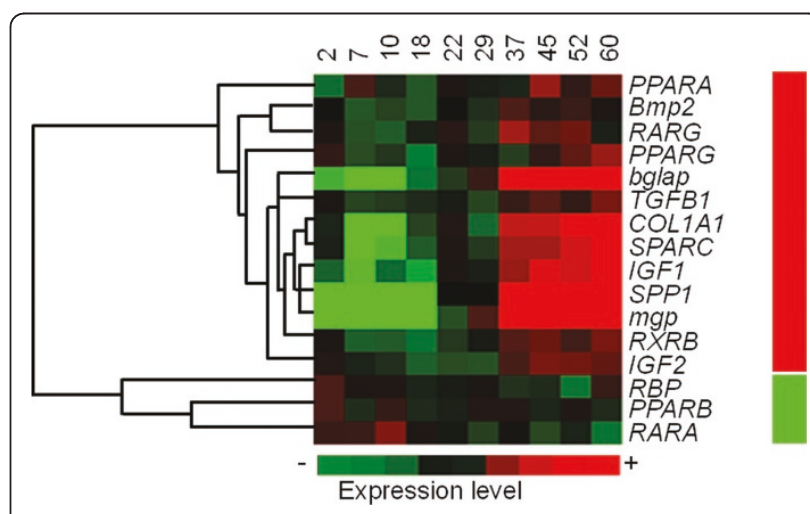

Figure 7 Hierarchical clustering of the 16 target genes analysed based on mRNA expression, showing the cluster of the different studied genes with similar expression profile during larval development. Columns represent the mean data values for each of the 10 sampling times (days post hatching; dph) and rows represent single genes. Expression level of each gene is represented relative to its median abundance across the different stages and is depicted by a colour scale: green, black, and red indicating low, medium, and high relative expression levels, respectively. Coloured bars to the right indicate the location of two gene clusters: red corresponds to genes with a progressive increase in mean gene expression level from 2 to $60 \mathrm{dph}$; and green with those whose mean gene expression level decreased progressively from an initial relative high level of expression. 
Regarding RA nuclear receptors, $R A R A$ presented at $18 \mathrm{dph}$ a significant up-regulation (1.6 fold change respect to the control group) in $10 \times \mathrm{VA}$ larvae with respect to control fishes (REST, $P<0.05$; Figure $8 \mathrm{a}$ ); however no significant up- or down-regulation of RARA was found at $60 \mathrm{dph}$ regardless of the dietary conditions (REST, $P>0.05$; Figure $8 \mathrm{a}$ ). In contrast, while no differences in $R A R G$ mean gene expression ratio were found at $18 \mathrm{dph}$ in larvae fed with increased dietary VA content $(1.5 \times \mathrm{VA}$ and $10 \times \mathrm{VA})$, a slight but significant RARG down-regulation (1.2 and 1.32 fold change, respectively) was found with respect to control larvae at 60 dph (REST, $P<0.05$; Figure 8a). Interestingly, no change in gene expression was found concerning the

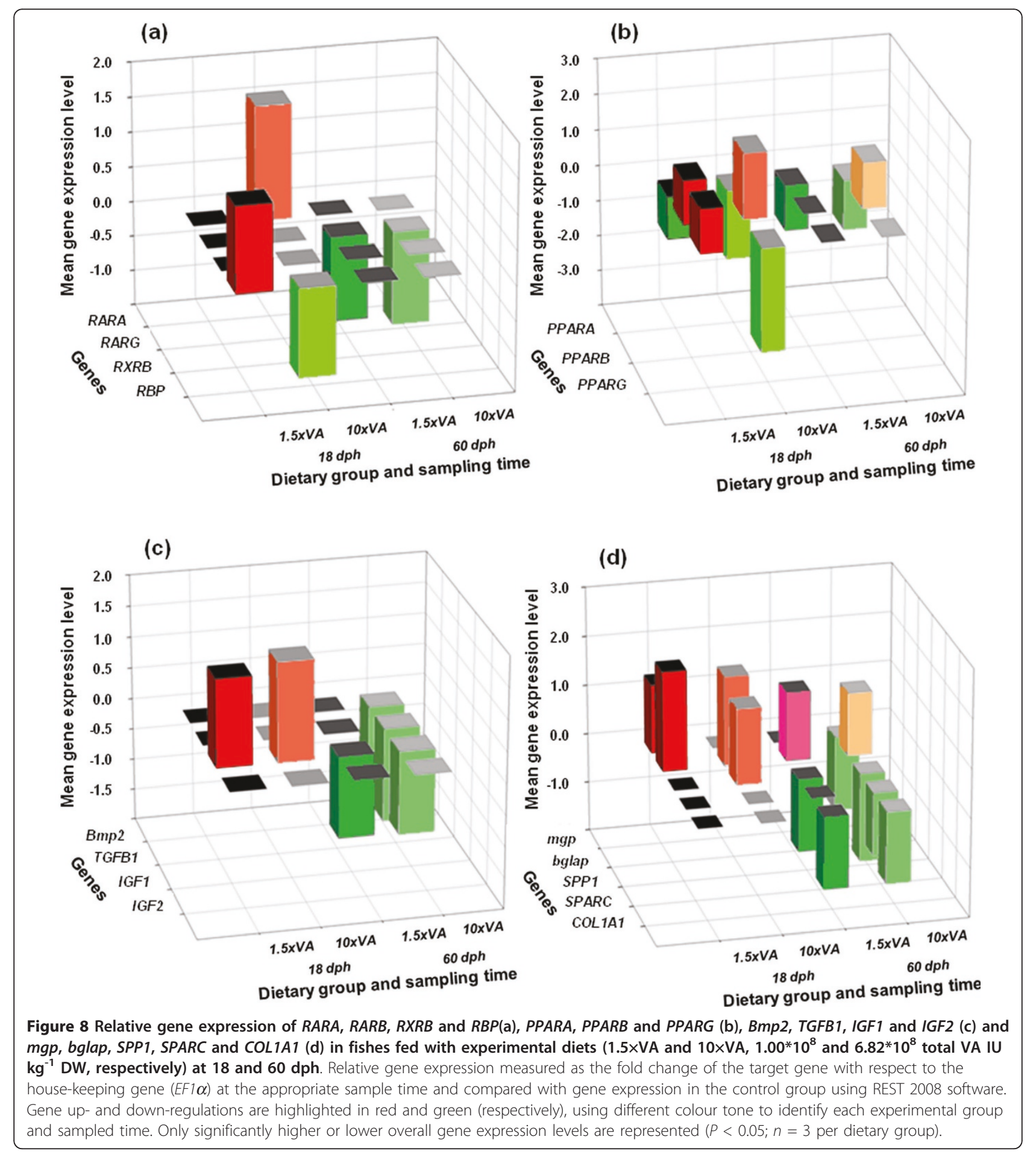


gene $R X R B$ at both sample times analyzed (REST, $P>$ 0.05; Figure 8a).

At $18 \mathrm{dph}$, an inverse correlation between increasing dietary VA and RBP gene expression was observed (Figure 8a). Larvae fed with a moderate increase in dietary VA content $(1.5 \times \mathrm{VA})$ showed a significant up-regulation in the $R B P$ gene expression ratio (1.23 fold change respect to the control group), whereas those animals fed with the highest levels of VA in diet $(10 \times \mathrm{VA})$ presented a down-regulation with respect to control larvae (1.3 fold change; REST, $P<0.05$; Figure $8 \mathrm{a}$ ). However, no significant differences in $R B P$ gene expression ratios were found at $60 \mathrm{dph}$ between experimental groups (REST, $P>0.05$; Figure $8 \mathrm{a}$ ).

Expression levels of PPARs were also affected by dietary VA levels, however each one to a different extent (Figure 8b). Larvae fed with higher dietary levels of VA $(1.5 \times \mathrm{VA}$ and $10 \times \mathrm{VA})$ presented a significant downregulation in PPARA at both sample times analyzed (18 and $60 \mathrm{dph}$ ); up to 1.9 fold change in $10 \times \mathrm{VA}$ larvae at $18 \mathrm{dph}$ compared with control larvae (REST, $P<0.05$; Figure $8 \mathrm{~b}$ ). In contrast, larvae fed with higher VA diets showed a significant up-regulation in PPARB gene expression (up to 1.82 fold change in $10 \times \mathrm{VA} 18 \mathrm{dph}$ larvae) with respect to control larvae (REST, $P<0.05$; Figure $8 b$ ), whereas no differences were observed in larvae from the $1.5 \times \mathrm{VA}$ group at $60 \mathrm{dph}$. Interestingly, PPARG showed a contrary effect to the increase of VA dietary content at $18 \mathrm{dph}$. While there was a slight significant up-regulation in $1.5 \times \mathrm{VA}$ larvae (1.2 fold change with respect to control fish; REST, $P<0.05$; Figure $8 \mathrm{~b}$ ), $10 \times$ VA larvae exhibited a significant down-regulation (ca. 2.87 fold change with respect to the control group; REST, $P<0.05$; Figure $8 \mathrm{~b})$. However, no differences in gene expression ratio were found in $1.5 \times \mathrm{VA}$ and $10 \times \mathrm{VA}$ larvae at $60 \mathrm{dph}$ (REST, $P>0.05$; Figure $8 \mathrm{~b}$ ).

At the end of the feeding phase with high dietary VA content (18 dph), Bmp 2 and TGFB1 did not present significantly different gene expression ratios in larvae fed with supplemented VA diets $(1.5 \times \mathrm{VA}$ and $10 \times \mathrm{VA})$ compared with those from the control group (REST, $P>$ 0.05 ; Figure $8 \mathrm{c}$ ). This pattern was also observed at 60 dph in $1.5 \times$ VA larvae. However, Bmp2 and TGFB1 gene expression levels were significantly reduced with a 1.57 and 1.5 fold change (respectively) at $60 \mathrm{dph}$ in larvae fed with the highest dietary VA content $(10 \times \mathrm{VA})$ with respect to control larvae (REST, $P<0.05$; Figure 8c). The IGF axis showed different responses to dietary VA content (Figure 8c). IGF1 gene expression was upregulated in larvae fed with higher dietary VA levels at $18 \mathrm{dph}$ (1.4 and 1.6 fold change in $1.5 \times \mathrm{VA}$ and $10 \times \mathrm{VA}$, respectively) with respect to the control group (REST, $P<0.05)$; whereas a significant down-regulation at $60 \mathrm{dph}$ (between 1.11 and 1.14 fold change) in IGF1 transcription was found with respect to the control group (REST, $P<0.05$ ). Interestingly, IGF2 expression was not significantly different among experimental groups at both analyzed sampling times (REST, $P>$ 0.05).

Genes encoding extracellular matrix (ECM) proteins were also differentially affected by dietary VA content (Figure $8 \mathrm{~d}$ ). The expression of $m g p$ gene from $1.5 \times \mathrm{VA}$ larvae at $18 \mathrm{dph}$ was significantly up-regulated (1.39 fold change) compared with the control larvae (REST, $P<$ 0.05 ), while non-significant differences were found in $10 \times$ VA larvae (REST, $P>0.05$ ). Conversely, at $60 \mathrm{dph}$ mRNA levels of $m g p$ in $1.5 \times$ VA larvae was no significantly different with respect to the control group (REST, $P>0.05)$; whereas $10 \times \mathrm{VA}$ larvae presented a significantly lower gene expression ratio (1.5 fold change) than the control larvae (REST, $P>0.05$ ). Furthermore, the gene encoding the other Gla protein analyzed (bglap) showed significantly higher gene expression levels at $18 \mathrm{dph}$ (2.02 and 1.81 fold change in $1.5 \times \mathrm{VA}$ and $10 \times$ VA larvae, respectively) in groups fed with higher dietary VA content than the control (REST, $P<0.05$ ). The effect of increasing dietary VA level at $60 \mathrm{dph}$ was the same in $1.5 \times \mathrm{VA}$ and $10 \times \mathrm{VA}$ larvae. Fish from both treatments showed significant up-regulation on bglap expression (1.39 and 1.29 fold change) with respect to control larvae (REST, $P<0.05)$. In addition, when analyzing the expression of genes encoding matricellular proteins, SPP1 did not show significant differences in $1.5 \times \mathrm{VA}$ larvae with respect to control larvae at $18 \mathrm{dph}$. However, a significantly higher gene expression ratio (1.54 fold change) was found in $10 \times \mathrm{VA}$ larvae compared to the control group (REST, $P<0.05$ ). Furthermore, SPP1 was down-regulated at $60 \mathrm{dph}$ in both larvae fed with higher VA dietary content (1.48 and 1.78 fold change in $1.5 \times \mathrm{VA}$ and $10 \times \mathrm{VA}$, respectively) with respect to the control group (REST, $P>0.05$ ). Interestingly, $S P A R C$ only showed significant differences in expression in $10 \times \mathrm{VA}$ larvae at $60 \mathrm{dph}$ with respect to the control group (REST, $P<0.05$ ), being lower by a 1.28 fold change. Finally, mRNA levels of COL1A1 were not affected by the dietary level of VA when compared to the experimental groups (REST, $P>0.05$ ) at $18 \mathrm{dph}$. However, at $60 \mathrm{dph}$ gene expression of COL1A1 was significantly lower in $1.5 \times \mathrm{VA}$ and $10 \times \mathrm{VA}$ larvae $(1.45$ fold change for both $1.5 \times \mathrm{VA}$ and $10 \times \mathrm{VA}$ groups) as compared to the control group (REST, $P<0.05$ ).

\section{Discussion}

The present study analysed the expression profile of several gene markers for skeletogenesis during the larval development in gilthead sea bream, and the influence of dietary hypervitaminosis A on their expression. Reliable nutritional, physiological and gene expression results 
can be drawn from this work, as results in growth (dry weight and standard length) fell within the range of previously reported values $[30,31]$. Results from this study supported the idea that dietary VA content controlled normal fish development through binding of its active metabolite, retinoic acid (RA), with specific nuclear receptors RARs and RXRs, and regulated target genes expression levels including retinoic receptors themselves. However, as RNA extractions were obtained from pooled whole larvae, the expression profiles of each gene reflect the expression level from a mix of different cell types and tissues. Thus, the variation of gene expression ratios observed during larval development under standard conditions could reflect changes in proportions of different tissues throughout ontogenesis and/or gene expression regulation in a specific tissue. In this sense, two different types of gene expression profiles during gilthead sea bream larval development were found by hierarchical clustering, showing that transcription is time- and tissue-dependent for each gene. For example, it is evident that higher expression of genes encoding ECM proteins are correlated with body growth, as increased fish size requires increasing bone strength and skeleton size in order to support the increased body weight. As ECM genes are expressed only in specific tissues (e.g. skeleton), the disruption of their tissue and developmental stage dependent expression by VA could be inferred; whereas it would remain unclear for the other genes that are ubiquitously expressed (e.g. IGFs, PPARs, Bmp2 and TGFB1), since their disruption would be masked by the overall expression in other tissues.

\section{Retinoid Receptors}

The different expression profiles of RARA, RARG and $R X R B$ found in this study supported the hypothesis that each gene had a temporal and spatial specific expression; suggesting specific roles for each of them $[13,32,33]$; in which contrasted with the suggested redundancy among them as found in mouse null mutant studies [34]. Previous works pointed out that RARA plays a crucial role in vertebrate RA signalling, being ubiquitously expressed in embryonic and adult mammal $[35,36]$ and fish tissues [13]. However, the reported evolution of RARA gene expression in this study is not in agreement with that found by Villeneuve and coworkers [13], where European sea bass RARA gene expression increased from 10 to $42 \mathrm{dph}$. It is possible that although both fish species are evolutionarily closely related, their timing of development is quite different, which may explain the above-mentioned differences. Interestingly, the fact that $R A R A$ is predominantly expressed at $5 \mathrm{dph}$ in the jaws of European sea bass [13], supports the idea that high expression of RARA observed in 10xVA larvae may be specifically implicated in the development of jaw deformities detailed in our previous work [18]. Two factors would explain the high RARA gene expression found in $10 \times \mathrm{VA}$ larvae compared to $1.5 \times \mathrm{VA}$ and control larvae: (i) the transcriptional activation of RARA through the presence of a RARE in its promoter [7], is due to an increase in RA levels; and (ii) the increased gene expression of Cyp26 enzymes mediated through RAR $\alpha$ receptor, in order to degrade the excessive RA into other metabolites [37]. Under normal conditions, chondrogenesis is accompanied by a decrease in RARA expression [38], a process that normally takes place at $10 \mathrm{dph}$ in gilthead sea bream. This result supports the idea that the overexpression of RARA was dietary induced by an increase of VA, as reported in fish exposed to Am80 (a RAR-selective agonist [39]), RA [32] or hypervitaminosis A [16]. In addition, high transcription levels of $R A R A$ might be directly responsible for the disruption of normal patterns of skeletogenesis, and could be responsible for the high incidence of skeletal deformities found in fish fed with high levels of VA [18]. The RARA disruption might have also activated a downstream gene cascade, including Hoxd-4 and Shh [40] that would also have affected larval morphogenesis [41], and delaying the maturation of the digestive system as it was found at $18 \mathrm{dph}$ larvae from the $10 \times$ VA group [18]. Furthermore, such differences in the development of the digestive system were not observed at $60 \mathrm{dph}$ [18], when VA imbalance was corrected and $R A R A$ expression was normalized in relation to the control group.

The expression pattern of RARG during larval development suggests that this gene plays a crucial role in the transcriptional RA signal regulation during vertebrate morphogenesis, chondrogenesis and differentiation of squamous epithelia $[42,43]$. Our results show that the RARG gene expression ratio was highest between 37 and $52 \mathrm{dph}$, which is concomitant with the onset of the typical adult skin development in gilthead sea bream; and in concordance with that reported in European sea bass between 10-42 dph [13]. The modulation of RARG expression by hypervitaminosis $\mathrm{A}$ has been demonstrated in mammals [44] and fishes $[16,17,32]$. Nevertheless, no regulation of RARG expression by hypervitaminosis A was detected in gilthead sea bream larvae at $18 \mathrm{dph}$. This might be due to the fact that chondrogenesis in chondral bones is almost completed at that stage of development $[9,11]$, and $R A R G$ is expressed at a lower level in hypertrophic than in pre-hypertrophic chondrocytes [45]. In contrast to $18 \mathrm{dph}$, larvae aged $60 \mathrm{dph}$ exhibited a downregulation of $R A R G$ in $1.5 \times \mathrm{VA}$ and $10 \times \mathrm{VA}$ groups, which under present experimental conditions seemed to be linked to different rates of larval development 
(e.g. chondrogenesis and skin differentiation) among dietary treatments.

The role of RXRs on retinoid signal transduction during development of vertebrates depends on each subtype. Despite null $R X R B$ or $R X R G$ mutant mice being viable, and do not display VA associated abnormalities, RXRA null mutants die [34]. In teleosts, $\mathrm{RXR} \alpha$ is involved in the development of the anterior hindbrain, tailbud, neural crest, pharynx and fins; whereas RXR $\beta$ played different roles in early larval development; and $\mathrm{RXR} \gamma$ plays a key role in brain and nervous system development and function [26]. In the present study, the ontogenic increase in expression of $R X R B$ during the standard experimental trial was in agreement with previously reported results [16], and it is related to the development of those tissues where $R X R B$ is mainly expressed [26]. The expression levels of $R X R B$ in gilthead sea bream larvae were not affected by high levels of dietary VA, which seems to confirm that all-trans-RA (the most abundant RA isomer in nature) does not bind to this nuclear receptor nor is it transcriptionally activated by RAREs [46].

In this study, we present data from gene expression at specific time points, which is a static representation of a dynamic process involving the formation of homo- and heterodimers of the translated proteins leading to downstream cascades of gene expression. Variations in RARRXR homo-/heterodimer equilibrium have been shown to cause severe abnormalities in zebrafish embryos [47]. Thus, abnormal skeletogenesis and/or morphogenesis in gilthead sea bream could be interpreted as a perturbation of the nuclear RAR-RXR homo-/heterodimer equilibrium, as higher amount of RARA transcripts could induce increased formation of RAR $\alpha$-RXR heterodimers or decreased formation of RXR heterodimers with its different partners (VDR, TR, PPARs, etc).

\section{Retinol-Binding Protein}

Retinol Binding Protein (RBP) is reputed for transporting retinol from the liver to different target tissues [48]. In agreement with previous studies in fish [48] and other vertebrates [49], RBP gene expression was low during larval development, and remained constant until metamorphosis. Such low RBP expression might be due to either low retinol mobilization requirements during early fish larval development, or to the fact that the daily requirements for VA were already fulfilled. Therefore, retinol mobilization from liver to target tissues was not needed, and consequently the RBP not transcribed. When gilthead sea bream larvae were fed with moderately increased levels of VA $(1.5 \times$ VA group $)$ at $18 \mathrm{dph}$, $R B P$ expression was up-regulated, whereas this gene was down-regulated in fish fed with the highest levels of VA (10×VA group). Those changes in RBP gene expression by the dietary VA levels may be due to transcriptional regulation through the double RARE in its promoter. Considering that VA homeostasis via its release from storage tissues is a tightly controlled process [50], we suggest that the observed $R B P$ gene expression in gilthead sea bream larvae in response to dietary VA content is part of a protective mechanism to avoid VA toxicity. Under slight dietary hypervitaminosis A $(1.5 \times$ VA group) conditions, an increase in RBP mRNA level could be directly induced by binding of ligand activated RARs and RXRs to its RARE [51]; whereas during exposure to elevated VA levels (10×VA group), a decrease in $R B P$ expression might take place to reduce the mobilization of VA from the adipose tissue and liver [52].

\section{Peroxisome proliferator-activated receptors}

The peroxisome proliferator-activated receptors (PPARs) are well known fatty acid and eicosanoid inducible nuclear receptors in vertebrates, playing multiple physiological functions [53]. Molecular studies recently showed that there exist differences in tissue expression and ligand-binding properties between fish and mammalian PPARs [54-56].

Considering that PPAR $\alpha$ is implicated in the regulation of fatty acid metabolism [27], the progressive increase in PPARA expression at late larval stages seemed to be correlated to larval growth and progressive differentiation of the liver, intestine and muscle, where this receptor is mainly expressed [54,57]. However, PPARA expression was down-regulated when larvae were exposed to high levels of dietary VA at $18 \mathrm{dph}$, which might be linked to the impaired maturation of the digestive system of $1.5 \times \mathrm{VA}$ and $10 \times \mathrm{VA}$ larvae in comparison to the control group [18]. This is in agreement with [54], PPARA expression being dependant on the nutritional status of the animal and its changing energy requirements during development. As PPAR $\alpha$ plays an important role in adipocyte differentiation in fishes [56], its down-regulation in gilthead sea bream early juveniles fed with hypervitaminosis A might have also perturbed the normal differentiation rate of mesenchymal cells into myogenic, osteogenic and/or adipocytic cells, leading to skeletal deformities.

PPAR $\beta$ in mammals is involved in the skeletal, brain and skin functions as well as in adipose tissue differentiation and fatty acid metabolism [58,59]. Its early expression in gilthead sea bream might be linked to the mobilization of endogenous reserves stored in the yolk sac [54] and to the synthesis and turnover of cellular membranes [60]. However, it did not correlate significantly with growth or fat deposition, as it has been previously reported in cobia (Rachycentron canadum) [57]. Increased expression of PPARB has been described in the early phase of adipogenesis in mammals [61] and 
red sea bream (Pagrus major) [56]; but in contrast to mammalian $P P A R B$, its expression in adipocytes did not seem to be under nutritional control. Primary osteoblastic cells showed a high expression of PPARB [59], then the higher gene expression of $P P A R B$ in $1.5 \times \mathrm{VA}$ and $10 \times \mathrm{VA}$ larvae compared to the control group at $18 \mathrm{dph}$ might indicate a premature osteoblastogenesis in those groups, as has been suggested in our previous study [18]. Interestingly, it has been reported that musclespecific overexpression of $P P A R B$ in mice resulted in a profound change in muscle fibre composition due to hyperplasia [62]. Impaired muscle development could in turn induce some vertebral deformities [63] and lead to those skeletal deformities (e.g. lordosis) reported in our previous study [18]. These changes in muscle were coupled with a reduction in the mass of body fat of mice [62] that may be in agreement with the gene expression of the above-mentioned PPARA and PPARG. In addition, $P P A R B$ was up-regulated in $10 \times \mathrm{VA}$ larvae at $60 \mathrm{dph}$, which could reflect a retarded adipogenesis. It is clear that more research is needed to reveal the role of PPAR $\beta$ in regulating the muscle fibre growth and the adiposity of marine fish, as well as the potential induction of skeletal deformities by such impaired muscle development.

In mammalians, PPAR $\gamma$ regulates adipogenesis at its early phase through heterodimerization with RXR [64]. In fish, it seems that PPAR $\gamma$ fulfil the same roles, although they are not activated by the same specific ligands [54]. Under normal rearing conditions, PPARG expression increased with gilthead sea bream ontogenesis similarly to data reported in cobia where PPARG expression increased with fish growth and fat deposition [57]. However, it has been reported that retinaldehyde (the metabolic precursor of RA) inhibits PPARG, resulting in a lower PPAR-RXR complex formation [65], which in turn could enhance osteogenesis instead of adipogenesis in mesenchymal cells. Thus, lower PPARG expression in fish fed with high levels of VA $(10 \times \mathrm{VA}$ group) at $18 \mathrm{dph}$ could reflect an enhancement of osteogenesis and disrupt normal skeletogenesis in gilthead sea bream larvae. This hypothesis is also reinforced by the increased blue coloured surfaces (chondrocytes) in both $1.5 \times \mathrm{VA}$ and $10 \times \mathrm{VA}$ larvae compared with control larvae.

\section{Growth Factors}

Skeletal cells synthesize different growth factors, such as fibroblast growth factor, platelet-derived growth factor, IGFs, TGF $\beta$, and additional cytokines. The expression of IGF1 is found in different soft and calcified tissues in adult gilthead sea bream [66], where three spliced variants with a specific pattern of expression have been found $[67,68]$. Our Taqman assay was designed to recognise all three IGF1 splice variants; therefore, our reported gene expression ratio for IGF1 is the sum of the expression for all three splice variants. In the present study, the progressive increase of IGF1 expression was in accordance with the high cell proliferation rate, and/or the increase in specific cell activity in different tissues during larval morphogenesis [66]. The dosedependent overexpression of IGF1 found at $18 \mathrm{dph}$ in gilthead sea bream larvae fed hypervitaminosis A, was in agreement with previous works $[16,69]$. The higher IGF1 expression in the $10 \times \mathrm{VA}$ group might be due to synergistic direct and indirect effects. The growth hormone promoter contains a RARE [70], and has been found to be regulated by RAR $\alpha / \gamma$ isoforms in pituitary cells of carp (Cyprinus carpio; [71]). In turn, increased RARA expression might induce growth hormone transcription and secretion, which finally would induce an increase in IGF1 hepatic transcripts. In addition, increased levels of thyroxin $\left(\mathrm{T}_{4}\right)$ were observed in fish under hypervitaminosis $\mathrm{A}$ [19], while $\mathrm{T}_{4}$ is reported to induces IGF1 expression in in vitro fish studies [72]. Then, it seems plausible that the increase in expression of IGF1 in gilthead sea bream larvae fed with high VA levels $(1.5 \times \mathrm{VA}$ and $10 \times \mathrm{VA}$ groups) could be due also to increased $\mathrm{T}_{4}$ levels. Such high IGF1 expression, which is known to promote muscle differentiation and growth [73], coupled with that of PPARB, might have caused an imbalance in the development of the musculoskeletal system in gilthead sea bream fed with high levels of VA, leading to a higher incidence of lordosis in those larvae [18].

In the present study, the abrupt increase in IGF2 expression recorded at the end of the larval phase (29 $\mathrm{dph}$ ) corresponds with the onset of ossification in most of the bone structures $[9,11]$, which is mainly due to its role in osteoblast proliferation and differentiation [74]. In contrast to IGF1, the expression of IGF2 in gilthead sea bream fed with hypervitaminosis A was not disrupted, supporting the idea that different hormonal signals and mechanisms of gene transcription control the regulation of expression of both IGF forms [67].

Other growth factors such as transforming growth factors beta (TGF $\beta$ s) or the bone morphogenetic proteins (BMPs) are important for the development of bone, among other tissues [29]. Among those BMP's, BMP-2 plays a key role in bone development, inducing the differentiation of mesenchymal cells into osteoblast precursors and promoting the maturation of osteoblasts through the expression of $R u n x 2 / C b f a 1$ [75]. TGF $\beta 1$ is involved in the regulation of a broad range of biological processes, including cell proliferation, differentiation and migration, production of extracellular matrix [76], as well as maintaining bone homeostasis and turnover [77]. In our study, the gene expression profile of $B m p 2$ in 
larvae reared under standard conditions seemed to correlate with the biological function of BMP2. Bmp2 expression between 18 and $22 \mathrm{dph}$ might be associated with the onset of pre-osteoblasts proliferation $[9,11]$; whereas the observed tendency of $B m p 2$ to increase between 29 and $37 \mathrm{dph}$ might be due to its role as a promoter of osteoblast differentiation. Furthermore, increased expression of TGFB1 was concomitant with an increase in expression of several genes encoding ECM proteins, as has been reported [76].

$B m p 2$ expression in early larval stages (18 dph) fed with hypervitaminosis A was not affected. However, the possibility cannot be neglected that in those larvae RA might have disrupted Bmp2 expression prior to our sampling point, as has been shown in vitro studies [33]. In contrast, $B m p 2$ was down-regulated in $10 \times \mathrm{VA}$ larvae at $60 \mathrm{dph}$, suggesting a negatively controlled regulation of Bmp2 [78]. This down-regulation of Bmp2 concomitant with lower $R A R G$ gene expression is in accordance with the reported loss of the RA-inducible expression of $B m p 2$ in the absence of RARG gene expression [33]. In addition, the $B m p 2$ down-regulation might downregulate the expression of ECM encoding genes ( $m g p$, SPP1, SPARC, COL1A1) observed in 10×VA larvae through the transcriptional regulation of Runx2/Cbfa1 [78].

BMP-2 and TGF $\beta 1$ have opposing actions on osteoblast function and differentiation. While BMP-2 enhances Runx2/Cbfa1 expression, TGF $\beta 1$ inhibits its expression; then, both genes regulate the coordinated expression of several genes encoding ECM proteins [78]. The fact that both genes (Bmp2 and TGFB1) were down-regulated in gilthead sea bream larvae fed with hypervitaminosis $\mathrm{A}(10 \times \mathrm{VA}$ group) at $60 \mathrm{dph}$, could be explained by the ubiquitous expression of TGFB1 which had a variety of other biological functions and therefore, this down-regulation of TGFB1 may not be representative of the skeletal tissue alone.

\section{Genes encoding bone extracellular matrix proteins}

Until the beginning of the ossification process at $18 \mathrm{dph}$ (5.7-6.0 mm standard length; [9], gene expression profiles of the genes encoding ECM proteins ( $m g p$, bglap, SPP1, SPARC and COL1A1) showed low gene expression values. These results were in accordance with the ongoing development of most skeletal structures, that were not yet ossified, with the exception of some located in the viscerocranial and caudal region [9-11]. Higher gene expression was found from $37 \mathrm{dph}$ onwards, concomitantly with the intense ossification of most of the bone structures, such as vertebrae centra (9.0-9.4 mm standard length; [9]). The expression of ECM proteins progressively increased during larval ontogeny. However, the significant increases of each gene occurred at different developmental times, the first to increase being $S P A R C$ and SPP1, followed by $m g p$, and finally by that of COL1A1 and bglap, which shows the progression of gene transcription of specific bone matrix development markers.

The early increase in expression of SPARC during gilthead sea bream ontogenesis reflects the many key processes during early larval development in which that protein is involved, showing an enhanced expression in areas undergoing chondrogenesis, osteogenesis, somitogenesis and angiogenesis [79]. SPARC is also reputed for inhibiting adipogenesis and enhancing osteoblastogenesis and fibrogenesis in rainbow trout [80], as well as for participating in the final mineralization and remodelling of the ECM. Our increase in SPARC expression during gilthead sea bream larval development is in agreement with that reported in rainbow trout (Oncorhynchus mykiss) [80], but was contrary to the results found in gilthead sea bream [79]. Although results are methodologically incompatible with those of [79] for comparative purposes, the increase in expression of SPARC during early larval ontogeny would seem more plausible, considering the participation of SPARC in many biological processes. Regarding SPP1, its early increased expression might be attributed to the differentiation of hypertrophic chondrocytes and osteoblasts [81].

In mammals, MGP is a decisive factor for differentiation and maturation of chondrocytes and a key regulator of chondral and intramembranous ossification [82]. In fish, branchial arches are the sites with higher levels of mgp expression, followed by the heart, vertebra, kidney and liver [83]. Thus, increased gene expression during larval ontogeny in our experiment could reflect the development of the above-mentioned organs and vital systems in order to match the biological needs of the developing larva.

COL1A1 is mainly expressed in connective tissues and is abundant in bone, cornea, and dermis, and in two cell types, osteoblasts and fibroblasts. Collagen fibres comprise $90 \%$ of the ECM proteins in skeletal tissues and confer most of their physical properties [84]. The present ontogeny of the COL1A1 expression was in agreement with previous results found in European sea bass, where COL1A1 was highly expressed from $31 \mathrm{dph}$ onwards [14]. According to this data, the earlier increase in COL1A1 expression in comparison to that of blap is in agreement with the temporal coordination of both ECM encoding genes [85]. Osteocalcin is a specific bone marker [86] that is required for the correct maturation of hydroxyapatite crystals during the process of calcification [87]. However, the relationship between osteocalcin and mineralization remains unclear even within the same species, since some authors detected bglap prior to mineralization and others at the onset or after the 
beginning of mineralization [82]. Its early detection at 2 $\mathrm{dph}$, in contrast to the previous reported detection in gilthead sea bream at $37 \mathrm{dph}$ [86], might be linked to the different molecular techniques used, since qPCR is more sensitive than Northern blot analysis. This earlier detection, prior to the development of mature osteoblasts and calcification processes, might be linked to its expression in chondrocytes undergoing chondral calcification, as reported in zebrafish [82]. However, the increase in bglap expression at older stages of development $(52-60 \mathrm{dph})$ seemed to be due to the completion of the ossification of skeletal structures in the axial skeleton $[9-11,18]$, similar to that found in European sea bass $[88,89]$. Considering that osteopontin and osteocalcin are involved in the modulation of hydroxyapatite crystallization [90], the advanced SPP1 expression might be related to the inhibition of osteoblast mineralization [91] occurring in vertebrae centra during their intramembranous ossification, thus allowing osteoblast to maintain their proliferative state; while bglap expression would be an indicator of the osteoblast mineralization in those structures [89].

The colour pixel analysis of skeletal structures revealed that bone development was affected by hypervitaminosis $\mathrm{A}$, showing a disequilibrium between bone and cartilage, as $1.5 \times \mathrm{VA}$ and $10 \times \mathrm{VA}$ larvae display higher amounts of cartilage and lower values of red/blue coloration ratio with respect to the control group, respectively. Those lower ratios are in agreement with higher growth of some cartilage elements leading to the fusion of caudal fin complex structures [18]. Those differences in bone mineralization levels and ossification processes were reflected by changes in gene transcription, describing two different scenarios of mineralization stage for particular skeletal elements (splanchnocranium, dorsal and caudal fin elements) depending on the dietary VA level. Through its active metabolite RA, VA promotes terminal differentiation of hypertrophic chondrocytes [92], which could explain the higher amount of cartilage tissue in $1.5 \times \mathrm{VA}$ and $10 \times \mathrm{VA}$ larvae. Furthermore, $m g p$ over-expression in $1.5 \times \mathrm{VA}$ larvae at $18 \mathrm{dph}$ indicated an abnormal development of cartilage, as $m g p$ has been reported to control bone mineralization [93]. In contrast, high levels of VA in $10 \times \mathrm{VA}$ larvae induced advancement of the mineralization process of chondral structures leading to a higher mineralization stage [18]. Such advanced mineralization could be explained by the down-regulation of $m g p$ in $10 \times \mathrm{VA}$ larvae at $60 \mathrm{dph}$ and the higher expression of SPP1 at $18 \mathrm{dph}$ compared to control and $1.5 \times \mathrm{VA}$ larvae, as osteopontin is involved in osteoblast differentiation [91]. These results are in agreement with those reported in cell culture studies [94] and in vivo experiments [4]. At the end of the study, the down-regulation of SPP1 in $1.5 \times \mathrm{VA}$ and
$10 \times$ VA larvae might be considered as another sign of an abnormal osteoblast development, since SPP1 likely plays a key role in determining the biochemical properties of the bone [81]. In addition, another sign of the advancement of the mineralization process in skeletal structures in $10 \times \mathrm{VA}$ larvae was the down-regulation of SPARC at $60 \mathrm{dph}$.

Regarding bglap transcriptional regulation, it was upregulated at $18 \mathrm{dph}$ in $1.5 \times \mathrm{VA}$ and $10 \times \mathrm{VA}$ larval groups, reflecting an earlier chondral ossification of some skeletal elements derived from the splanchnocranium (e.g. maxillar, premaxillar, Meckel's cartilage, articular) which are the unique skeletal structures that were ossifying during that stage of development [11]. This precocious ossification process could be responsible for the high incidence of deformities in the abovementioned structures described in our previous study [18]. Furthermore, at the end of the study (60 dph), fish fed with higher levels of VA $(1.5 \times \mathrm{VA}$ and $10 \times \mathrm{VA})$ showed a higher bglap expression than those from the control group. The over-expression of bglap in the fish fed hypervitaminosis A indicated an increased ongoing osteogenic processes, as those larvae presented a higher amount of osteogenic tissue (sum of red and blue coloured surfaces) compared to the control group. Consequently, present results suggest that if normal ranges for bglap expression are established, this gene might be a reliable marker for detecting disorders in bone formation and mineralization processes $[95,89]$.

Finally, results of COL1A1 expression were not as informative as the other analyzed genes from the ECM regarding the skeletogenesis process. No changes in gene expression were found in COL1A1 in larvae fed with hypervitaminosis $\mathrm{A}$ at $18 \mathrm{dph}$ compared to the control group, even though it has been shown that this gene contains a RARE in its promoter [6]. Different results from the effects of RA on the expression of COL1A1 are reported in the literature [6], which suggests an indirect regulation of COL1A1 by RA. However, larvae from the $1.5 \times \mathrm{VA}$ and $10 \times \mathrm{VA}$ groups showed lower expression of COL1A1 at $60 \mathrm{dph}$, which seems to be attributed to the lower expression of $R A R G$ detected in those animals, since this $R A R$ binds specifically to the RARE of the COL1A1 promoter [84].

\section{Conclusions}

The present study showed that the analysed gene expression patterns in the gilthead sea bream were correlated with skeletogenesis during early larval development, as they showed a temporally coordinated gene expression for specific markers of the ECM. Furthermore, results from this study supported the idea that perturbations in specific dietary nutrients can alter normal anatomic development mediated by specific genes 
controlled by ligand-receptor interactions. Although both experimental groups $(1.5 \times \mathrm{VA}$ and $10 \times \mathrm{VA})$ were fed with an excess of VA, there were differences in their juvenile phenotype depending on the degree of hypervitaminosis A. $1.5 \times \mathrm{VA}$ and $10 \times \mathrm{VA}$ larvae were fed respectively with moderate and high dietary VA content (1.5 and up to 10 fold increase of VA content in the diet with respect to the control group). From this we conclude, only hypervitaminosis $\mathrm{A}$ in the $10 \times \mathrm{VA}$ group impaired larval performance in terms of growth, maturation of the digestive system and survival rate, in which the down-regulation of $R B P$ is illustrative of excessive dietary VA. However, both doses of VA differentially affected the coordinated expression of genes during skeletogenesis, some of them being markers for the differences in the processes of chondrogenesis and osteoblastogenesis observed among dietary groups at early stages of larval development (i.e., PPARG and $m g p$ for $1.5 \times \mathrm{VA} ; R A R A$ and $S P P 1$ for $10 \times \mathrm{VA})$. In particular, the up-regulation of bglap in $1.5 \times \mathrm{VA}$ and $10 \times \mathrm{VA}$ larvae indicated an advanced ossification in some skeletal structures. Early disturbance of skeletogenesis were still manifest after 40 days, as revealed by differences in gene expression, highlighting the importance of a good nutritional balance during larval development that determines juvenile phenotype.

Concluding, present results showed that fish are reliable animal models to study the effects of nutritional hypervitaminosis A. However, since only global effects of dietary VA on fish larval physiology could be inferred from this study due to the use of whole organisms, in vitro research with bone cell lines is needed to understand the mechanisms by which RA controls skeletogenesis.

\section{Methods}

\section{Larval rearing and diets}

Gilthead sea bream larvae (1 dph) were obtained from a Spanish private hatchery and shipped to the IRTA facilities. After their acclimation, larvae were distributed at an initial density of 100 larvae $\mathrm{L}^{-1}$ in 2 and 24 cylindrical tanks, of 500 and $100 \mathrm{~L}$ respectively, connected to a water recirculation unit. Water conditions were as follows: $18-19^{\circ} \mathrm{C}, 35$ ppt salinity, $\mathrm{pH}$ 7.8-8.2. Water was provided with gentle aeration and oxygenation $(>4 \mathrm{mg}$ $\mathrm{1}^{-1}$ ) and $20 \%$ was exchanged daily. Photoperiod was 12L:12 D, and light intensity of 500 lux at water surface. All animal experimental procedures were conducted in compliance with the experimental research protocol approved by the Committee of Ethic and Animal Experimentation of the IRTA (reference number 6213038983898-4-8), which followed the international principles of replacement, reduction and refinement for the use of animals in research.
On one hand, in order to characterize gene expression patterns of selected genes during larval development until the juvenile stage, larvae kept in $500 \mathrm{~L}$ cylindrical tanks were reared following a commercial production procedure. Feeding schedule was as follows: from day 4 to 20 post hatch (dph) rotifers (Brachionus plicatilis), whose density was progressively increased from 5 to 10 rotifers $\mathrm{mL}^{-1}$; Artemia nauplii (EG, INVE, Belgium) from 16 to $22 \mathrm{dph}$, in increasing density from 0.5 to 2 nauplii $\mathrm{mL}^{-1}$, and 2 days enriched-metanauplii from 20 to $40 \mathrm{dph}$ ( 1 to 5 metanauplii $\mathrm{mL}^{-1}$ ). Both live preys were enriched with Easy Selco (ES; INVE, Belgium) according to manufacturer's instructions. From $36 \mathrm{dph}$ to the end of the experiment (60 dph), larvae were progressively weaned onto dry feed, first with Proton $1 / 2$ and 1/4 (INVE, Belgium) and then with Gemma Micro (size range: 75 to 500 $\mu \mathrm{m}$; Skretting, Spain). On the other hand, larvae kept in $100 \mathrm{~L}$ tanks were reared in order to evaluate the effects of high dietary VA content on gilthead sea bream larval performance and quality ([18], as well as skeletogenesis-related gene expression (present work). Feeding sequence and dietary experimental conditions are described in detail in [18]. In brief, three different dietary regimes (each one in triplicate) were evaluated during the early larval development (rotifer feeding phase), containing graded levels of VA. The graded VA levels in live prey were obtained by adding retinol palmitate $\left(1,600,000 \mathrm{IU} \mathrm{g}^{-1}\right.$, Sigma-Aldrich, Spain) to the commercial enriching emulsion, Easy Selco $^{\mathrm{TM}}(\mathrm{ES}$, INVE, Belgium). Those dietary treatments are referred to as Control, $1.5 \times \mathrm{VA}$ and $10 \times \mathrm{VA}$; and contained a mean of $0.66 * 10^{8}, 1.00 * 10^{8}$ and $6.82 * 10^{8}$ total VA IU $\mathrm{kg}^{-1}$ DW in enriched rotifers [18], while mean total vitamin A content in larvae was 60157, 71617 and $72909 \mathrm{IU} \mathrm{g}^{-1}$ DW at $18 \mathrm{dph}$ respectively.

\section{Sample collection}

Biological samples were taken at 2, 7, 10, 18, 22, 29, 37, 45,52 and $60 \mathrm{dph}$, in order to establish the gene expression patterns of skeletogenesis-related genes and larval growth during larval development. In order to evaluate gene expression regulation by hypervitaminosis $\mathrm{A}$ and bone mineralization, larvae reared under hypervitaminosis A were sampled at $18 \mathrm{dph}$, coinciding with the end of the nutritional challenge with VA (end of rotifer-feeding phase) and the onset of mineralization of the skeleton [9-11], and the end of the weaning period (60 dph). In all cases, larvae were sacrificed with an overdose of anaesthetic (Tricaine methanesulfonate, MS-222, Sigma). In both experiments, samples were frozen in RNA later $\left(\right.$ Ambion ${ }^{\circledR}$ ) and stored at $-80^{\circ} \mathrm{C}$ until gene expression analysis. 


\section{Larval growth and bone mineralization}

For larval growth, sampled larvae $(n=15)$ from each tank were washed with distilled water to avoid marine salts and used for body length and dry weight determination. Larval standard length was measured with a digital camera connected to a binocular microscope Nikon SMZ 800, AnalySIS (Soft Imaging Systems, $\mathrm{GmbH}$ ). Once larvae lengths were measured, they were dried at $60^{\circ} \mathrm{C}$ until their weight was constant. Weights were obtained with an analytic microbalance Sartorius BP211 D. Thirty larvae per dietary group (ten larvae per tank) were stained with alcian blue and alizarin red $\mathrm{S}$ [18] in order to evaluate the level of bone mineralization under different nutritional circumstances and quantified as described in [22], using a computerized image analysis package (IMAQ Vision Builder, National Instruments, Austin, TX). Total red and blue pixels were considered as a marker of the relative ratio of osteoblasts and chondrocytes (respectively) and normalized by larvae body surface, as larval size were highly variable within tanks.

\section{RNA extraction and QPCR conditions}

Total RNA was extracted from pools of fish larvae (100 to 5 individuals per sample time and tank depending of fish size) using the TRIzol reagent (Invitrogen ${ }^{\circledR}$, San Diego, CA, USA) as specified by the manufacturer. The quantity of RNA isolated was determined using a GeneQuant spectrophotometer (Amersham Biosciences), measuring optical density at $260 \mathrm{~nm}$ and its purity was established by the absorbance ratio $260 / 280 \mathrm{~nm}$ (1.72.0). The quality of the RNA was examined using $1.2 \%$ agarose gel electrophoresis. A reverse transcription reaction was carried out using equal quantities of total RNA $(1 \mu \mathrm{g})$ from each sample and Quanti Tect Reverse Transcription Kit (Qiagen ${ }^{\circledR}$ ). Electrophoresis using a 1.2\% agarose gel was run to assess the RT-PCR product.

Real-time qPCR was performed using an ABI PRISM 7300 (Applied Biosystems). For each gene, a speciesspecific Taqman assay was designed (Applied Biosystems) using the sequences acquired from the GenBank database (Table 1). The efficiency of the Taqman assay for each gene was previously evaluated to assure that it was close

Table 1 Accession number, primers and probes used for relative quantification of gene expression during gilthead sea bream ontogenic development and dietary vitamin A nutritional imbalance

\begin{tabular}{|c|c|c|c|}
\hline Gene name & Genebank & Component & $5^{\prime}$ to $3^{\prime}$ nucleotide sequences \\
\hline \multirow[t]{3}{*}{ RARA } & EU643830 & Forward & CCTGTCTGGACATCCTGATACTTC \\
\hline & & Reverse & CGTGAGTCCATCTGAGAAAGTCAT \\
\hline & & FAM probe & CTCTGGTGTGTAGCGTGTAC \\
\hline \multirow[t]{3}{*}{$R A R G$} & EU643831 & Forward & GTGCGTAATGACAGAAACAAGAAGA \\
\hline & & Reverse & ACTCCTCTAGCTCTCCACTTAGC \\
\hline & & FAM probe & CTITCTGGAAGCACCACCTC \\
\hline \multirow[t]{3}{*}{$R X R B$} & AM980430 & Forward & CCTGAGGCCCATGCAATCTC \\
\hline & & Reverse & ACACACATGCGTTTCTGAGACAA \\
\hline & & FAM probe & CAGCCCTGGACTAATG \\
\hline \multirow[t]{3}{*}{$\overline{P P A R A}$} & AY590299 & Forward & CTITTCGTGGCTGCCATTATCTG \\
\hline & & Reverse & CTCCACCAAAGGCACATCCA \\
\hline & & FAM probe & CCTGGGCGATCTCC \\
\hline \multirow[t]{3}{*}{ PPARB } & AY590301 & Forward & GTTTGTTGCTGCCATCATTCTCT \\
\hline & & Reverse & CACCTGCTTCACGTTCATTAGC \\
\hline & & FAM probe & CCGGGACGATCTCCAC \\
\hline \multirow[t]{3}{*}{$\overline{P P A R G}$} & AY590304 & Forward & CAATGTCGGCATGTCACACAAC \\
\hline & & Reverse & СTCCTTCTCCGCCTGGG \\
\hline & & FAM probe & CCGGCCAAAACGAATG \\
\hline \multirow[t]{3}{*}{ IGF1 } & AY996779 & Forward & GGGCGAGCCCAGAGA \\
\hline & & Reverse & GCCGTAGCCAGGTITACTGAAATAA \\
\hline & & FAM probe & TCCACACACAAACTGC \\
\hline \multirow[t]{3}{*}{$\overline{\text { IGF2 }}$} & AY996778 & Forward & GTCGGCCACCTCTCTACAG \\
\hline & & Reverse & TGCTTCCTTGAGACTTCCTGTTT \\
\hline & & FAM probe & TTACCCGTGATGCCCC \\
\hline \multirow[t]{3}{*}{ Bmp2 } & AY500244 & Forward & GTGGCTTCCATCGTATCAACATIIT \\
\hline & & Reverse & GCTCCCCGCCATGAGT \\
\hline & & FAM probe & CAGGAGCTCCAAATAA \\
\hline
\end{tabular}


Table 1 Accession number, primers and probes used for relative quantification of gene expression during gilthead sea bream ontogenic development and dietary vitamin A nutritional imbalance (Continued)

\begin{tabular}{|c|c|c|c|}
\hline \multirow[t]{3}{*}{$\overline{T G F B 1}$} & AF424703 & Forward & TITCCAACTTCGGCTGTACTGT \\
\hline & & Reverse & GAGATGCCAAAACTGAAGGTACTGA \\
\hline & & FAM probe & ATTGCGGCCGTTCTAG \\
\hline \multirow[t]{3}{*}{$\overline{R B P}$} & AY550957 & Forward & TGGCCACCTTCGAGACAAC \\
\hline & & Reverse & GATGCGGCTCCCCAGTAG \\
\hline & & FAM probe & CCCCGCCAAGTTCAG \\
\hline \multirow[t]{3}{*}{ mgp } & AY065652 & Forward & CGCCCGAAATACACCTCAGA \\
\hline & & Reverse & GACGGACGGATACTAGGAGTCTA \\
\hline & & FAM probe & ACCAGCCGCGACTCG \\
\hline \multirow[t]{3}{*}{ bglap } & AF048703 & Forward & CGAGCACATGATGGACACTGA \\
\hline & & Reverse & GTCCGTAGTAGGCCGTGTAG \\
\hline & & FAM probe & CAGCGATGATTCCC \\
\hline \multirow[t]{3}{*}{$\overline{C O L 1 A 1}$} & DQ324363 & Forward & GGCAACAGTCGCTTCACCTA \\
\hline & & Reverse & CCCCATGTACCGGTGTGT \\
\hline & & FAM probe & ACGTGCATCCATCCTC \\
\hline \multirow[t]{3}{*}{$\overline{S P P 1}$} & AY651247 & Forward & CCAGCCAGGAGTCAGAGGAT \\
\hline & & Reverse & ACTCTCATCTGAGTCGCTGTCA \\
\hline & & FAM probe & CTGCTCTGGCTCTCC \\
\hline \multirow[t]{3}{*}{ SPARC } & AJ564190 & Forward & AAGCTGCACCTCGACTACATC \\
\hline & & Reverse & CCTTCAGCTCGCTGTCCAT \\
\hline & & FAM probe & CAGGGCTCGATCATTT \\
\hline \multirow[t]{3}{*}{$\overline{E F 1 \alpha}$} & AF184170 & Forward & CCCGGTATGGTTGTCACCTT \\
\hline & & Reverse & GGTGCATCTCCACAGACTTGAC \\
\hline & & FAM probe & CCCCAGCTGACCACTG \\
\hline$\overline{185}$ & & \multicolumn{2}{|c|}{ TaqMan $^{\mathbb{R}}$ Gene Expression Assay\Eukaryotic $18 \mathrm{~S}$ rRNA, 20X (Part Number 4331182) } \\
\hline
\end{tabular}

to $100 \%$. All reactions were performed in 96 well plates in triplicate in $20 \mu \mathrm{l}$ reaction volumes containing: $10 \mu \mathrm{l}$ of $2 \times$ TaqMan universal PCR master mix (Applied Biosystems); $1 \mu \mathrm{l}$ of the $20 \times$ Taqman primer/probe solution corresponding to the analyzed gene; $8 \mu \mathrm{l}$ of molecular biology grade water; and $1 \mu \mathrm{l}$ of cDNA diluted 1:10, with the exception of bglap, which was evaluated with straight dilution. Standard amplification parameters were as follows: $95^{\circ} \mathrm{C}$ for $10 \mathrm{~min}$, followed by 45 amplification cycles, each of which comprised $95^{\circ} \mathrm{C}$ for $15 \mathrm{~s}$ and $60^{\circ} \mathrm{C}$ for $1 \mathrm{~min}$. Real time qPCR was performed for each gene, and therefore, a calibrator sample was included within each plate.

\section{Data processing}

The relative gene expression ratio for each gene was based on the PCR efficiency (E) and Ct of a sample compared with the control, and expressed in comparison to the reference gene, according to Pfaffl's mathematical model:

\footnotetext{
Ratio $=\frac{E \text { target gene }(\mathrm{dCt} \text { target gene }(\text { control }- \text { sample }))}{E \text { endogenous control gene }(\mathrm{dCt} E F 1 \alpha \text { RNA (control }- \text { sample }))}$
}

Statistical differences in gene expression between different developmental stages in larval rearing under standard conditions were analyzed by ANOVA, while differences in gene expression ratios between dietary treatments at each sampled time in larval rearing under hypervitaminosis A were performed by randomization tests using REST 2008 software [96].

As reference genes, $18 S$ and $E F 1 \alpha$ were evaluated as those have been suggested to be reliable house-keeping genes for qPCR analyses of developmental processes [97]. However, results were finally evaluated only with $E F 1 \alpha$ as the reference gene, due to the low efficiency of the $18 S$ Taqman probe $(<90 \%)$. In the Control group, target and housekeeping gene expressions were measured at $2,7,10,18,22,29,37,45,52$ and $60 \mathrm{dph}$ using gene expression at $2 \mathrm{dph}$ as the reference time point, to establish the normal ontogeny of target gene expression; while in the excess dietary VA groups $(1.5 \times \mathrm{VA}$ and $10 \times \mathrm{VA}$ ) the relative gene expression of the same target genes was evaluated at 18 and $60 \mathrm{dph}$, using the control group gene expression as the reference.

A supervised hierarchical clustering was applied [98] to the samples from the larval rearing under standard 
conditions and each gene was classified according to its gene expression profile. Tree View software, was used to generate visual representations of the classification [98].

In order to represent gene expression of target genes in a more comprehensive manner, gene expression ratios in larval rearing under hypervitaminosis A were reported as fold change regulation, and then ratios between 0 and 1 were transformed and represented as $-1 /$ (target gene ratio).

\section{List of abbreviations}

bglap: osteocalcin or bone Gla protein gene; BMPs: bone morphogenetic proteins; BMP-2: bone morphogenetic protein 2; Bmp2: bone morphogenetic protein 2 gene; Cbfa1: core binding factor a 1 protein; Cbfa1: core binding factor a 1 gene; COLIA1: type I collagen a1 chain gene: Ct: Cycle threshold; dl: decilitre; dph: days post hatch; DW: dry weight; E: efficiency; ECM: extracellular matrix proteins; EFla: elongation factor 1 a gene; GH: growth hormone protein; GH: growth hormone gene; Gla: y-carboxyglutamic acid; IGF-I: insulin-like growth factor I protein; IGF1: insulin-like growth factor I gene; IGF-II: insulin-like growth factor II protein; IGF2: insulin-like growth factor II gene; MGP: matrix Gla protein; mgp: matrix Gla protein gene; mRNA: messenger ribonucleic acid; PPARa: peroxisome proliferator-activated receptor a protein; PPARA: peroxisome proliferator-activated receptor a gene; PPAR $\beta$ : peroxisome proliferator-activated receptor $\beta$ protein; PPARB: peroxisome proliferator-activated receptor $\beta$ gene; PPAR $\gamma$ : peroxisome proliferator-activated receptor $\gamma$ protein; PPARG : peroxisome proliferatoractivated receptor $\gamma$ gene; GPCR: semiquantitative polymerase chain reaction; RA: retinoic acid; RARa: retinoic acid receptor a protein; RARA: retinoic acid receptor a gene;RARB: retinoic acid receptor $\beta$ protein; RARB: retinoic acid receptor $\beta$ gene; RARE: retinoic acid response element; RARY: retinoic acid receptor $\gamma$ protein; RARG: retinoic acid receptor $\gamma$ gene; RBP: retinol binding protein; RBP: retinol binding protein gene; REST: Relative expression software tool; RNA: ribonucleic acid; RXRa: retinoid $\times$ receptor a protein; RXRA: retinoid $\times$ receptor a gene; RXR $\beta$ : retinoid $\times$ receptor $\beta$ protein; $R X R B$ : retinoid $\times$ receptor $\beta$ gene; RXRY: retinoid $\times$ receptor $\gamma$ protein; $R X R G$ : retinoid $\times$ receptor $\gamma$ gene; Run $\times 2$ : runt related transcription factor 2 protein; shh: Sonic hedge hog gene; SL: standard length; SPARC: secreted protein acidic and rich in cysteine; SPARC: secreted protein acidic and rich in cysteine gene; SPP1: osteopontin gene; $T_{4}$ : thyroxin; TGF $\beta 1$ : transforming growth factor $\beta 1$ protein; TGFB1: transforming growth factor $\beta 1$ gene; TR: thyroid receptor; VA: vitamin A; VDR: vitamin D receptor.

\section{Acknowledgements}

Authors are greatly indebted to the technical staff of IRTA-Sant Carles research centre for their excellent technical assistance during larvae trials with gilthead seabream, especially to M. Monllaó, and J. Canoura; as well as B. Desbruyères from IFREMER-Brest research centre for its technical assistance in bone mineralization analysis. Funding was provided to EG by the Ministry of Science and Innovation of the Spanish Government (MINCINN, projects AGL2005-02478, HF2008-0079 and AGL2008-03897-C0401). I.F was supported by a predoctoral fellowship (reference BES-200612650).

\section{Author details}

${ }^{1}$ Unitat de Cultius Experimentals, IRTA Centre de Sant Carles de la Ràpita (IRTA-SCR), Crta. del Poble Nou s/n, 43540 - Sant Carles de la Ràpita (Spain). ${ }^{2}$ Nutrition Aquaculture and Genomics Research Unit, UMR 1067, IFREMER Marine Fish Nutrition Team. IFREMER, Technopole Brest-Iroise, BP 70, 29280 Plouzané (France).

\section{Authors' contributions}

IF participated in the design of the nutritional dose-response experiment and conducted it, carried out the gene expression analyses and drafted the manuscript. MD participated in the gene expression analyses and in the final redaction of the manuscript. KA designed and optimized gene expression analyses and participated in the final redaction of the manuscript. DM and $\mathrm{JZ}$ participated in the gene expression analysis and in the final redaction of the manuscript. EG got the funding, conceived part of the study, participated in the experimental design and in the final redaction of the manuscript. All authors read and approved the final manuscript.

Received: 17 September 2010 Accepted: 9 February 2011 Published: 9 February 2011

\section{References}

1. Witten PE, Huysseune A: Mechanisms of chondrogenesis and osteogenesis in fins. In Fins and Limbs; Development, Evolution and Transformation. Edited by: Hall BK. Chicago: Chicago University Press; 2007:79-92.

2. Sire JY, Donoghue PCJ, Vickaryous MK: Origin and evolution of the integumentary skeleton in non-tetrapod vertebrates. J Anat 2009, 214:409-440.

3. Haga Y, Suzuki T, Takeuchi T: Retinoic acid isomers produce malformations in postembryonic development of flounder, Paralichthys olivaceus. Zool Sci 2002, 19:1105-1112.

4. Haga Y, Dominique VJ, Du SJ: Analyzing notochord segmentation and intervertebral disc formation using the twhh: gfp transgenic zebrafish model. Transgen Res 2009, 18:669-683.

5. Trayhurn P: Nutritional genomics - "Nutrigenomics". Br J Nutr 2003, 89:1-2.

6. Balmer JE, Blomhoff R: Gene expression regulation by retinoic acid. J Lipid Res 2002, 43:1773-1808.

7. Balmer JE, Blomhoff R: A robust characterization of retinoic acid response elements based on a comparison of sites in three species. J Steroid Biochem Mol Biol 2005, 96:347-354.

8. Ross SA, Caffery PJ, Draguer UC, De Luca LM: Retinoids in embryonal development. Physiol Rev 2000, 80:1021-1054.

9. Faustino M, Power DM: Development of osteological structures in the sea bream: vertebral column and caudal fin complex. J Fish Biol 1998, 52:11-22.

10. Faustino M, Power DM: Development of the pectoral, pelvic, dorsal and anal fins in cultured sea bream. J Fish Biol 1999, 54:1094-1110.

11. Faustino M, Power DM: Osteologic development of the viscerocranial skeleton in sea bream: alternative ossification strategies in teleost fish. J Fish Biol 2001, 58:537-572.

12. Gavaia PJ, Dinis MT, Cancela ML: Osteological development and abnormalities of the vertebral column and caudal skeleton in larval and juvenile stages of hatchery-reared Senegal sole (Solea senegalensis). Aquaculture 2002, 211:305-323.

13. Villeneuve L, Gisbert E, Cahu CL, Le Gall MM, Zambonino-Infante JL: Expression and localization of some retinoid receptors during European sea bass (Dicentrarchus labrax) larvae development. Aquaculture 2004, 242:537-551.

14. Darias MJ, Zambonino-Infante JL, Hugot K, Cahu CL, Mazurais D: Gene expression patterns during the larval development of European sea bass (Dicentrarchus labrax) by microarray analysis. Mar Biotechnol 2008, 10:416-428.

15. Sarropoulou E, Kotoulas G, Power DM, Geisler R: Gene expression profiling of gilthead sea bream during early development and detection of stress-related genes by the application of CDNA microarray technology. Physiol Genomics 2005, 23:182-191.

16. Villeneuve L, Gisbert E, Le Delliou H, Cahu CL, Zambonino-Infante JL: Dietary levels of all-trans retinol affect retinoid nuclear receptor expression and skeletal development in European sea bass larvae. $\mathrm{Br} J$ Nutr 2005, 93:791-801.

17. Villeneuve L, Gisbert E, Moriceau J, Cahu CL, Zambonino JL: Intake of high levels of vitamin $A$ and polyunsaturated fatty acids during different developmental periods modifies the expression of morphogenesis genes in European sea bass (Dicentrarchus labrax). Br J Nutr 2006, 95:677-687.

18. Fernández I, Hontoria F, Ortiz-Delgado JB, Kotzamanis Y, Estévez A, Zambonino-Infante $J \mathrm{~L}$, Gisbert E: Larval performance and skeletal deformities in farmed gilthead sea bream (Sparus aurata) fed with graded levels of Vitamin A enriched rotifers (Brachionus plicatilis). Aquaculture 2008, 283:102-115.

19. Fernández I, Pimentel MS, Ortiz-Delgado JB, Hontoria F, Sarasquete C, Estévez A, Zambonino-Infante JL, Gisbert E: Effect of dietary vitamin A on Senegalese sole (Solea senegalensis) skeletogenesis and larval quality. Aquaculture 2009, 295:250-265. 
20. Fernández I, Gisbert E: Senegalese sole bone tissue originated from chondral ossification is more sensitive than dermal bone to high vitamin A content in enriched Artemia. J Appl Icthyol 2010, 26:344-349.

21. Geay F, Darias MJ, Santigosa E, Desbruyères E, Quazuguel P, ZamboninoInfante JL, Cahu CL, Mazurais D: Cloning of endothelin-1 (ET-1) from European sea bass (Dicentrarchus labrax) and its gene expression analysis in larvae with retinoic acid-induced malformations. Aquaculture 2009, 287:169-173.

22. Mazurais D, Glynatsi N, Darias MJ, Christodoulopoulou S, Cahu CL, Zambonino-Infante $\mathrm{J}$, Koumoundouros G: Optimal levels of dietary vitamin A for reduced deformity incidence during development of European sea bass larvae (Dicentrarchus labrax) depend on malformation type. Aquaculture 2009, 294:262-270.

23. Ferraresso S, Milan M, Pellizzari C, Vitulo N, Reinhardt R, Canario AVM, Patarnello T, Bargelloni L: Development of an oligo DNA microarray for the European sea bass and its application to expression profiling of jaw deformity. BMC Genomics 2010, 11:354-371.

24. Hale AL, Tallafuss A, Yan Y, Dudley L, Eisen JS, Postlethwait JH: Characterization of the retinoica cid receptor genes raaa, rarab and rarg during zebrafish development. Gene Expr Patterns 2006, 6:546-555.

25. Tallafuss A, Hale LA, Yan Y, Duley L, Eisen JS, Postlethwait JH: Characterization of retinoid-X receptor genes rxra, rxrab, rxrbb and rxrg during zebrafish development. Gene Expr Patterns 2006, 6:556-565.

26. He Ch, Wang Ch, Li B, Xie F, Chen Y, Zuo Z: Tissue-specific and embryonic expression of the retinoid $\times$ receptors in Sebastiscus marmoratus. Comp Biochem Physiol B 2009, 154:221-228.

27. Desvergne $B$, Wahli W: Peroxisome proliferator-activated receptors: Nuclear control of metabolism. Endocr Rev 1999, 20:649-688.

28. Napoli JL: Biochemical pathways of retinoid transport, metabolism, and signal transduction. Clin Inmunol Inmunopathol 1996, 80(Suppl 3):52-62.

29. Rosen V: BMP2 signaling in bone development and repair. Cytokine Growth F R 2009, 20:475-480.

30. Tandler A, Anav FA, Choshniak I: The effect of salinity on growth rate, survival and swimbladder inflation in gilthead seabream, Sparus aurata, larvae. Aquaculture 1995, 135:343-353.

31. Saka S, Çoban D, Kamaci HO, Süzer C, Firat K: Early development of cephalic skeleton in hatchery-reared gilthead seabream, Sparus aurata. Turk J Fish Aquat Sc 2008, 8:341-345.

32. Joore J, van der Lans GB, Lanser PH, Vervaart JM, Zivkovic D, Speksnijder JE, Kruijer W: Effects of retinoic acid on the expression of retinoic acid receptors during zebrafish embryogenesis. Mech Dev 1994, 46:137-150.

33. Boylan JF, Lufkin T, Achkar CC, Taneja R, Chambon P, Gudas LJ: Targeted Disruption of Retinoic Acid Receptor a (RARa) and RARy Results in Receptor-Specific Alterations in Retinoic Acid-Mediated Differentiation and Retinoic Acid Metabolism. Mol Cell Biol 1995, 15:843-851.

34. Kastner P, Mark M, Ghyselinck N, Krezel W, Dupé V, Grondona JM, Chambon P: Genetic evidence that the retinoid signal is transduced by heterodimeric RXR/RAR functional units during mouse development. Development 1997, 124:313-326.

35. Lufkin T, Lohnes D, Mark M, Dierich A, Gorry P, Gaub MP, LeMeur M, Chambon P: High postnatal lethality and testis degenerationin retinoic acid receptor a mutant mice. Proc Natl Acad Sci 1993, 90:7225-7229.

36. Ruberte $E$, Dollé $P$, Chambon $P$, Morriss-Kay G: Retinoic acid receptors and cellular retinoid binding proteins. II. Their differential pattern of transcription during early morphogenesis in mouse embryos. Development 1991, 111:45-60.

37. Reijntjes S, Blentic A, Gale E, Maden M: The control of morphogen signalling: Regulation of the synthesis and catabolism of retinoic acid in the developing embryo. Dev Biol 2005, 285:224-237.

38. Shimono K, Morrison TN, Tung W, Chandraratna RA, Williams JA, Iwamoto M, Pacifici M: Inhibition of Ectopic Bone Formation by a Selective Retinoic Acid Receptor a-Agonist: A New Therapy for Heterotopic Ossification? Inc J Orthop Res 2010, 28:271-277.

39. Haga $Y$, Suzuki T, Kagechika H, Takeuchi T: A retinoic acid receptorselective agonist causes jaw deformity in the Japanese flounder, Paralichthys olivaceus. Aquaculture 2003, 221:381-392.

40. Suzuki T, Oochara I, Kurokawa T: Retinoic acid given at late embryonic stage depresses sonic hedgehog and Hoxd-4 expression in the pharyngeal area and induces skeletal malformation in flounder (Paralichthys olivaceus) embryos. Dev Growth Differ 1999, 41:143-152.
41. Dollé P, Ruberte E, Leroy P, Morriss-Kay G, Chambon P: Retinoic acid receptors and cellular retinoid binding proteins I. A systematic study of their differential pattern of transcription during mouse Organogenesis. Development 1990, 110:1133-1151.

42. Ruberte E, Dollé P, Krust A, Zelent A, Morriss-Kay G, Chambon P: Specific spatial and temporal distribution of retinoic acid receptor gamma transcripts during mouse embryogenesis. Development 1990, 108:213-222.

43. Kim Y, Sharma RP: Histochemical localization of retinoic acid receptors in the developing hamster fetus. Reprod Toxicol 1995, 9:435-447.

44. Colon-Teicher LS, Raviprakash RD, Raghubir PS: Temporal expression of retinoic acid receptors in hamster fetus during organogenesis and alteration by retinoic acid treatment. Comp Biochem Physiol 1996, 114C:71-78.

45. Koyama E, Golden EB, Kirsch T, Adams SL, Chandraratna RAS, Michaille J, Pacifici M: Retinoid Signaling Is Required for Chondrocyte Maturation and Endochondral Bone Formation during Limb Skeletogenesis. Dev Biol 1999, 208:375-391.

46. Germain P, Chambon P, Eichele G, Evans RM, Lazar MA, Leid M, de Lera AR, Lotan R, Mangelsdorf DJ, Gronemeyer H: International Union of Pharmacology. LXIII. Retinoid $\times$ receptors. Pharmacol Rev 2006, 58:760-772.

47. Minucci S, Leid M, Toyama R, Saint-Jeannet JP, Peterson VJ, Hoern V, Ishmael JE, Bhattacharyya N, Dey A, Dawid IB, Ozato K: Retinoid $\times$ Receptor (RXR) within the RXR-Retinoic Acid Receptor Heterodimer Binds Its Ligand and Enhances Retinoid-Dependent Gene Expression. Mol Cell Biol 1997, 17:644-655.

48. Funkenstein B: Developmental expression, tissue distribution and hormonal regulation of fish (Sparus aurata) serum retinol-binding protein. Comp Biochem Phys B 2001, 129:613-622.

49. Sapin V, Ward SJ, Bronner S, Chambon P, Dollé P: Differential Expression of Transcripts Encoding Retinoid Binding Proteins and Retinoic Acid Receptors During Placentation of the Mouse. Dev Dyn 1997, 208:199-210.

50. Wolf G: Multiple functions of vitamin-A. Physiol Rev 1984, 64:873-937.

51. Jenssen KA, Satre MA: Mouse retinol binding protein gene: Cloning, expression and regulation by retinoic acid. Mol Cell Biochem 2000, 211:85-94.

52. Mercader J, Granados N, Bonet ML, Palou A: All-Trans Retinoic Acid Decreases Murine Adipose Retinol Binding Protein 4 Production. Cell Physiol Biochem 2008, 22:363-372.

53. Escher $P$, Wahli W: Peroxisome proliferator-activated receptors: insight into multiple cellular functions. Mutat Res 2000, 448:121-138.

54. Leaver MJ, Boukouvala E, Antonopoulou E, Diez A, Favre-Krey L, Ezaz MT, Bautista JM, Tocher DR, Krey G: Three Peroxisome Proliferator-Activated Receptor Isotypes from Each of Two Species of Marine Fish. Endocrinology 2005, 146:3150-3162.

55. Kondo H, Misaki R, Gelman L, Watabe S: Ligand-dependent transcriptional activities of four torafugu pufferfish Takifugu rubripes peroxisome proliferator-activated receptors. Gen Comp Endocr 2007, 154:120-127.

56. Oku H, Umino T: Molecular characterization of peroxisome proliferatoractivated receptors (PPARs) and their gene expression in the differentiating adipocytes of red sea bream Pagrus major. Comp Biochem Phys B 2008, 151:268-277.

57. Tsai ML, Chen HY, Tseng MH, Chang R: Cloning of peroxisome proliferators activated receptors in the cobia (Rachycentron canadum) and their expression at different life-cycle stages under cage aquaculture. Gene 2008, 425:69-78.

58. Lee CH, Olson P, Evans RM: Lipid Metabolism, Metabolic Diseases, and Peroxisome Proliferator-Activated Receptors. Endocrinology 2003, 144:2201-2207.

59. Giaginis C, Tsantili-Kakoulidou A, Theocharis S: Peroxisome proliferatoractivated receptors (PPARs) in the control of bone metabolism. Fundam Clin Pharm 2007, 21:231-244.

60. Braissant O, Wahli W: Differential expression of peroxisome proliferatoractivated receptor-alpha, -beta, and -gamma during rat embryonic development. Endocrinology 1998, 139:2748-2754.

61. Peters JM, Lee SST, Li W, Ward JM, Gavrilova O, Everett C, Reitman ML, Hudson LD, Gonzalez FJ: Growth, adipose, brain, and skin alterations resulting from targeted disruption of the mouse peroxisome proliferator-activated receptor beta (delta). Mol Cell Biol 2000, 20:5119-5128. 
62. Luquet S, Lopez-Soriano J, Holst D, Fredenrich A, Melki J, Rassoulzadegan M, Grimaldi PA: Peroxisome proliferator-activated receptor $\delta$ controls muscle development and oxydative capability. FASEB J 2003, 17:2299-2301.

63. Kranenbarg S, Waarsing JH, Muller M, Weinans $H$, van Leeuwen JL: Lordotic vertebrae in sea bass (Dicentrarchus labrax L.) are adapted to increased loads. J Biomech 2005, 38:1239-1246.

64. Tontonoz P, Hu E, Graves RA, Budavari Al, Spiegelman BM: mPPAR/2: tissue-specific regulator of an adipocyte enhancer. Gene Dev 1994, 8:1224-1234

65. Ziouzenkova O, Plutzky J: Retinoid metabolism and nuclear receptor responses: New insights into coordinated regulation of the PPAR-RXR complex. FEBS Letters 2008, 582:32-38.

66. Perrot V, Moiseeva EB, Gozes Y, Chan SJ, Ingleton P, Funkenstein B: Ontogeny of the Insulin-like Growth Factor System (IGF-I, IGF-II, and IGF1R) in Gilthead Seabream (Sparus aurata): Expression and Cellular Localization. Gen Comp Endocr 1999, 116:445-460.

67. Canalis E, McCarthy TL, Centrella M: Growth factors and cytokines in bone cell metabolism. Annu Rev Med 1991, 42:17-24.

68. Tiago DM, Laizé V, Cancela ML: Alternatively spliced transcripts of Sparus aurata insulin-like growth factor 1 are differentially expressed in adult tissues and during early development. Gen Comp Endocr 2008, 157:107-115.

69. Fu Z, Noguchi T, Kato H: Vitamin A deficiency reduces insulinlike growth factor (IGF)-I gene expression and increases IGF-I receptor and insulin receptor gene expression in tissues of Japanese Quail (Coturnix coturnix japonica). J Nutr 2001, 131:1189-1194.

70. Carnevali O, Cardinali M, Maradonna F, Parisi M, Olivotto I, PolzonettiMagni AM, Mosconi G, Funkenstein B: Hormonal Regulation of Hepatic IGF-I and IGF-II Gene Expression in the Marine Teleost Sparus aurata. Mol Reprod Dev 2005, 71:12-18.

71. Sternberg H, Moav B: Regulation of the growth hormone gene by fish thyroid/retinoid receptors. Fish Physiol Biochem 1999, 20:331-339.

72. Leung LY, Kwong AKY, Man AKY, Woo NYS: Direct actions of cortisol, thyroxin and growth hormone on IGF-I mRNA expression in sea bream hepatocytes. Comp Biochem Phys A 2008, 151:705-710.

73. Goldspink G, Yang SY: The splicing of the IGF-I gene to yield different muscle growth factors. Adv Genet 2004, 52:23-49.

74. McCarthy TL, Centrella M, Canalis E: Regulatory effects of insuline-like growth factors I and II on bone collagen synthesis in rat calvarial cultures. Endocrinology 1989, 124:301-309.

75. Marie PJ, Debiais F, Haÿ E: Regulation of human cranial osteoblast phenotype by FGF-2, FGFR-2 and BMP-2 signaling. Histol Histopathol 2002, 17:877-885.

76. Janssens K, ten Dijke P, Janssens S, Van Hul W: Transforming Growth Factor- $\beta 1$ to the Bone. Endocr Rev 2005, 26:743-774.

77. Canalis E, Economides AN, Gazzerro E: Bone Morphogenetic Proteins, Their Antagonists, and the Skeleton. Endocr Rev 2003, 24:218-235.

78. Shen ZJ, Kim SK, Jun DJ, Park W, Kim YH, Malter JS, Moon BJ: Antisense targeting of TGF- $\beta 1$ augments BMP-induced upregulation of osteopontin, type I collagen and Cbfa1 in human Saos-2 cells. Exp Cell Res 2007, 313:1415-1425.

79. Estêvão MD, Redruello B, Canario AVM, Power DM: Ontogeny of osteonectin expression in embryos and larvae of sea bream (Sparus auratus). Gen Comp Endocr 2005, 142:155-162.

80. Tang S, McKeown BA: Cloning and expression of the SPARC CDNA from rainbow trout. J Fish Biol 1997, 50:608-619.

81. Sodek J, Ganss B, McKee MD: Osteopontin. Crit Rev Oral Biol Med 2000, 11:279-303.

82. Gavaia PJ, Simes DC, Ortiz-Delgado JB, Viegas CSB, Pinto JP, Kelsh RN, Sarasquete MC, Cancela ML: Osteocalcin and matrix Gla protein in zebrafish (Danio rerio) and Senegal sole (Solea senegalensis): Comparative gene and protein expression during larval development through adulthood. Gene Expr Patterns 2006, 6:637-652.

83. Roberto VP, Cavaco S, Viegas CSB, Simes DC, Ortiz-Delgado JB, Sarasquete MC, Gavaia PJ, Cancela ML: Matrix Gla protein in turbot (Scophthalmus maximus): Gene expression analysis and identification of sites of protein accumulation. Aquaculture 2009, 294:202-211.

84. Meisler NT, Parrelli J, Gendimenico GJ, Mezick JA, Cutroneo KR: All-transretinoic acid inhibition of Proa1(I) collagen gene expression in fetal rat skin fibroblast: identification of a retinoic acid response element in the Proa1(I) collagen gene. J Invest Dermatol 1997, 108:476-481.

85. Ducy P, Starbuck M, Priemel M, Shen J, Pinero G, Geoffroy V, Amling M, Karsenty G: A Cbfa1-dependent genetic pathway controls bone formation beyond embryonic development. Gene Dev 1999, 13:1025-1036.

86. Pinto JP, Ohresser MCP, Cancela ML: Cloning of the bone Gla protein gene from the teleost fish Sparus aurata. Evidence for overall conservation in gene organization and bone-specific expression from fish to man. Gene 2001, 270:77-91.

87. Boskey AL, Gadaleta S, Gundberg C, Doty SB, Ducy P, Karsenty G: Fourier transform infrared microspectroscopic analysis of bones of osteocalcindeficient mice provides insight into the function of osteocalcin. Bone 1998, 23:187-196.

88. Darias MJ, Mazurais D, Koumoundouros G, Glynatsi N, Christodoulopoulou S, Desbruyeres E, Le Gall MM, Quazuguel P, Cahu CL, Zambonino-Infante JL: Dietary vitamin D3 affects digestive system ontogenesis and ossification in European sea bass (Dicentrachus labrax, Linnaeus, 1758). Aquaculture 2010, 298:300-307.

89. Darias MJ, Lan Chow Wing O, Cahu CL, Zambonino-Infante $J$, Mazurais D: Double staining protocol for developing European sea bass (Dicentrarchus labrax) larvae. J Appl Ichthyol 2010, 26:280-285.

90. Fonseca VG, Laizé V, Valente MS, Cancela ML: Identification of an osteopontin-like protein in fish associated with mineral formation. FEBS J 2007, 274:4428-4439.

91. Addison WN, Azari F, Sørensen ES, Kaartinen MT, McKee MD: Pyrophosphate inhibits mineralization of osteoblast cultures by binding to mineral, up-regulating osteopontin, and inhibiting alkaline phosphatase activity. J Biol Chem 2007, 282:15872-15883.

92. Iwamoto M, Shapiro IM, Yagami K, Boskey AL, Leboy PS, Adams SL, Pacifici M: Retinoic acid induces rapid mineralization and expression of mineralization-related genes in chondrocytes. Exp Cell Res 1993, 207:413-420.

93. Yagami K, Suh JY, Enomoto-Iwamoto M, Koyama E, Abrams WR, Shapiro IM, Pacifici M, Iwamoto M: Matrix GLA protein is a developmental regulator of chondrocyte mineralization and, when constitutively expressed, blocks endochondral and intramembranous ossification in the limb. J Cell Biol 1999, 147:1097-1108.

94. Cheung AMS, Tam CKH, Chow HCH, Verfaillie CM, Liang R, Leung AYH: Alltrans retinoic acid induces proliferation of an irradiated stem cell supporting stromal cell line AFT024. Exp Hematol 2007, 35:56-63.

95. Mazurais D, Darias MJ, Gouillou-Coustans MF, Le Gall MM, Huelvan C, Desbruyères E, Quazuguel P, Cahu CL, Zambonino-Infante JL: Dietary vitamin mix levels influence the ossification process in European sea bass (Dicentrarchus labrax) larvae. Am J Physiol Regul Integr Comp Physiol 2008, 294:520-527.

96. Gene-Quantification. [http://www.gene-quantification.de/rest-2008.html].

97. Mitter K, Kotoulas G, Magoulas A, Mulero V, Sepulcre P, Figueras A, Novoa B, Sarropoulou E: Evaluation of candidate reference genes for QPCR during ontogenesis and of immune-relevant tissues of European seabass (Dicentrarchus labrax). Comp Biochem Physiol B 2009, 153:340-347. 98. Gene Cluster. [http://rana.lbl.gov/].

doi:10.1186/1471-213X-11-7

Cite this article as: Fernández et al: Coordinated gene expression during gilthead sea bream skeletogenesis and its disruption by nutritional hypervitaminosis A. BMC Developmental Biology 2011 11:7. 